\title{
A Financial Stress Index to Identify Banking Crises
}

\author{
Alejandro Támola \\ Graduate Thesis -Universidad Nacional de La Plata \\ Advisor: Ricardo Bebczuk
}

October 2004

\footnotetext{
\# I am very thankful to my advisor, Ricardo Bebczuk for his able guidance and support throughout the process of writing this work. I am also grateful to Julieta Trías, for her infinite patience to listen my endless rumble. The usual disclaimer applies.
} 


\begin{abstract}
Motivated by discrepancies among widely used chronologies of banking crises in empirical studies, this work develops a financial stress index (FSI) and proposes its use as an alternative way to identify the presence of banking problems. This FSI differentiates from similar indexes, particularly because it is based on series available for a large set of countries and over extended periods. This work finds that this FSI permits deriving a chronology of banking crises in line with those provided in previous studies while, in turn, allows the identification of some usually unidentified episodes. Additionally, as an unexpected result, for countries with history of twin-crises, this work also detects a strong association between the FSI and the real exchange rate. This result is considered as providing additional support to the FSI ability to identify banking problems.
\end{abstract}

Motivado por las discrepancias presentes en las actuales cronologías de crisis bancarias, este trabajo desarrolla un índice de stress financiero y propone su utilización como herramienta alternativa para identificar la presencia de problemas bancarios. Este índice se diferencia de otras propuestas similares por la utilización de series disponibles para un amplio número de países y durante extensos períodos de tiempo. Se encuentra que mediante su utilización es posible derivar una cronología de crisis bancarias que compara favorablemente con estudios previos y que, además, permite la identificación de episodios usualmente no reconocidos. Adicionalmente, para países considerados con historial de crisis gemelas, se encuentra que el FSI muestra una clara asociación con la evolución del tipo de cambio real y otros indicadores de presión cambiaria, lo cual es considerado como un respaldo adicional a la validez del FSI como herramienta para la identificación de problemas bancarios. 


\section{Introduction}

Usually, the intensification of an economic phenomenon encourages interest in its study. These have been the cases of unemployment, hyperinflation and stagflation as well as balance-of-payments crises and sovereign defaults. More recently, the awake of a new wave of financial crises, particularly during the 1990s, gave new impulse to the study of financial problems. ${ }^{1}$ Because of this renewed boost, a large number of studies were devoted to the empirical analysis of this phenomenon. An important issue in these studies is the proper identification of crisis episodes. Accurate timing the occurrence of these events, including its eruption and duration, is a crucial requisite for an adequate study of it.

Sometimes, as in the case of sovereign defaults or balance-of-payments crises, identifying the beginning or duration of an episode may not be problematic. However, in other cases, identification may become rather controversial. Unfortunately, this latter is the case in empirical studies of banking problems. Discrepancies on identification of banking problems may emerge for different reasons, ranging from lack of adequate data to theoretical discrepancies.

Over the last few years, some efforts were devoted to this topic, leading to the appearance of some surveys of banking crises. However, the problem remains open as these surveys present important differences and discrepancies regarding crises' timing and duration -and even sometimes existence.

Differences regarding the timing and duration of banking crises may affect empirical studies. For instance, discrepancies may affect the results of Early Warning Models and the measurement of benefits from implementing prompt corrective policies. As shown in section II.B, even considering a sample of well-known and studied countries discrepancies may entail counting roughly $60 \%$ more cases and rising the average duration by one-third. This variation in the number of crisis episodes affects the measurement of crucial statistics, such as the noise-to-signal ratio in the case of EWMs, and divergences in measured average duration might affect the estimated relationship between the length and costs of banking crises. $^{2}$

Accurate timing of banking crises is also important for the study of contagion and implementation of policies aimed to its prevention. In this regard, 'small' variations in the timing of crises can lead to dramatic changes in the associated contagion pattern (particularly when episodes are dated in annual basis), therefore affecting a crucial aspect of the study. Moreover, prompt identification of regional banking problems might be important since it can provide the authorities with valuable additional time to design and implement preventive and/or resolution measures.

This work focuses on this issue and proposes an alternative methodology to identify banking problems, based on the use of a financial stress index (FSI) specifically developed to this task. The methodology departure from the usual event approach and proposes a continuous index to describe the evolution of the banking system, classifying some extreme realizations as crisis. ${ }^{3}$ This proposed FSI offers the following advantages: (i) through its use, it is possible to derive a chronology of banking crises in line with those of previous studies;

\footnotetext{
${ }^{1}$ Unless otherwise stated, the term financial crisis will be used as a synonymous of banking crisis.

2 At this point, it is useful stress differences between EWMs and Dating Crisis Literature (DCL). The latter attempts to establish the periods and places where banking crises are or were present and eventually estimate its costs. Instead, the former is intended to assess country vulnerabilities to banking crises and, more important, to forecast the likelihood of banking crisis. EWMs rely on the results provided by the DCL.

${ }^{3}$ Section II.A briefly sketches some pros and cons of the event approach.
} 
(ii) allows dating banking problems on monthly basis; (iii)since it is composed by a few widely and timely reported series, it can be easily replicated and applied to a large number of countries; (iv) because it is a continuous variable, its comparability with other continuous measures -such as the real exchange rate- is enhanced; (v) provided the index can be replicated for almost any country it may be used as an additional domestic and regional surveillance tool. ${ }^{4}$

This work is structured as follows: section II discusses some of the reasons originating discrepancies around banking crises dates and provides an example of these differences and its potential consequences. Section III develops a Financial Stress Index (FSI) and proposes its use as an alternative methodology to date banking crises. Next, section I.V. presents some applications of this FSI, including an alternative chronology of past banking crises based on this index. Section V offers some conclusions.

\section{Exploring the Banking Crises Identification Problem}

Empirical study of financial crises requires as a fundamental step an accurate delimitation of the event under consideration but, so far, there is relatively low agreement on both procedures to follow and variables to observe to establish the presence of financial problems. This relatively low level of agreement cause significant discrepancies among currently used chronologies of financial problems. ${ }^{5}$ This section looks at two aspects of these discrepancies. First, (point II.A) it reviews two possible sources of discrepancies between datasets, namely (lack of) analytical framework and different working definitions (including a short discussion on the pros and cons of these working definitions). The second part (point II.B) presents a quantitative example stressing differences among datasets.

\section{II.A. Some Sources of Discrepancy: Analytical Framework and Working Definitions}

Two important reasons underlying discrepancies around dates of banking problems are the lack of widely accepted analytical framework and the use of alternative working definitions.

\section{Analytical Framework as a Source of Discrepancies}

The financial system is a complex structure. Broadly defined it involves -among othershouseholds, nonfinancial enterprises, banks, insurance companies, stock markets, pension funds, hedge funds and the public sector interacting with each other in complex ways. ${ }^{6}$ This complexity is one of the reasons why still there is no widely accepted model or analytical framework for assessing financial or banking system instability (see Box 1 for a short review of some proposed analytical descriptions of financial instability or crises).

\footnotetext{
${ }^{4}$ Even though, the FSI is not intended to be an early warning.

5 This relatively low level of agreement is illustrated in section II.B. Additionally, a case-by-case list is presented with the survey of banking problems in Annex I.

${ }^{6}$ The public sector plays simultaneous, alternative roles. Operating similarly to private agents and defining the legal system, financial regulation frameworks, conducting surveillance and supervision operations and the monetary policy
} 
Thus, naturally, this lack of agreement on a proper analytical framework or theory defining a financial crisis translates into different working definitions of financial or banking crises, each one stressing different concepts.

\section{Working Definitions as Sources of Discrepancies}

As stated above, lack of a unified or widely accepted theory of banking crises translates into different empirical definitions of crises. ${ }^{7}$ The next paragraphs review definitions contained in works -widely cited as sources of crises dates- and then present some comments about them.

Lindgren, Garcia and Saal (1996). In their work, LGS present a 'survey of banking problems around the world' that classifies problems in three levels: crises, significant problems and problems not categorized as either class. Following Sundararajan and Baliño (1991), they define crises as cases where there were runs or other substantial portfolio shifts, collapses of financial firms or massive government intervention. Additionally, they characterize extensive unsoundness short of a crisis as significant problems. Finally, in episodes where problems in some banks did not have a significant impact on either the functioning of the banking sector as a whole or the macroeconomy are recorded -literallyas an unnamed category.

Caprio and Klingebiel (2003). CK define two categories of banking problems: systemic and borderline (nonsystemic) financial crises. The former are defined as a situation where as much or all of bank capital has been exhausted. They also identify 'borderline and smaller (nonsystemic) banking crises' but -again: literally- they do not explicitly provide a definition for this second type of problems.

Kaminsky and Reinhart (1999). KR identify only one category of problems, namely crises. In this work, banking crises are identified according to two criteria: (i) bank runs that lead to the closure, merging, or takeover by the public sector of one or more financial institutions; and (ii) if there are no runs, the closure, merging, takeover, or large-scale government assistance of an important financial institution (or group of institutions) that marks the start of a string of similar outcomes for other financial institutions As an interesting feature, KR also date when the banking crisis hits its peak, defined as the period with the heaviest government intervention and/or bank closures.

Demirgüç-Kunt and Detragiache (1998). Using the studies of Caprio y Klingebiel (1996), Drees and Pazarbasioglu (1995), Kaminsky and Reinhart (1996), Lindgren, Garcia and Saal (1996) and Sheng (1995) DK-D gather a set of episodes of banking distress. Then in order to identify full-fledged crises among these episodes they check whether one of the following conditions holds: (a) the ratio of nonperforming assets to total assets in banking system exceeded $10 \%$, (b) the cost of the rescue operation was at least 2 percent of GDP, (c) banking sector problems resulted in a large scale nationalization of banks and (d) extensive bank runs took place or emergency measures such as deposit freezes, prolonged bank holidays, or generalized deposits guarantees were enacted by the government in response to the crisis. Additionally, in some cases with insufficient information a classification was still made based on their best judgment.

It is instructive to comment on some general features of these definitions.

\footnotetext{
${ }^{7}$ Loosely speaking, for the purpose of this work an empirical definition differs from a theoretical definition in that the former are intended to derive a concrete measure or identification. For instance, hyperinflation may be empirically defined as episodes where actual inflation rates exceed $300 \%$ per year.
} 


\section{Table II.1. Summary of Concepts Used in Alternative Empirical Definitions}

\begin{tabular}{|c|c|c|c|c|}
\hline$\overline{\text { Concept used }}$ & $\overline{\mathrm{CK}}$ & LGS & KR & $\overline{\mathrm{DK}-\mathrm{D}}$ \\
\hline Bank runs & & $\mathrm{C}$ & $\mathrm{C}$ & \\
\hline Bank runs followed by government intervention & & & $\mathrm{C}$ & \\
\hline Collapses of financial firms & & $\mathrm{C}$ & & \\
\hline Government intervention $^{1}$ & & & $\mathrm{C}$ & \\
\hline (Massive) government intervention ${ }^{2}$ & & $\mathrm{C}$ & $\mathrm{C}$ & \\
\hline Bank capital & $\mathrm{C}$ & & & \\
\hline Soundness (bank capital + reserves) & & $\mathrm{C}$ & & \\
\hline Share of NPLs & & & & Q \\
\hline Rescue/resolution costs & & & & Q \\
\hline Impact on the banking system & & $\mathrm{C}$ & & \\
\hline Impact on the macroeconomy & & $\mathrm{C}$ & & \\
\hline \multicolumn{5}{|l|}{ Non-statistical sources } \\
\hline Previous studies & $\mathrm{C}$ & $\mathrm{C}$ & $\mathrm{C}$ & $\mathrm{C}$ \\
\hline Experts opinion, financial press & & $\mathrm{C}$ & $\mathrm{C}$ & \\
\hline \multicolumn{5}{|l|}{ Addenda } \\
\hline Number of classifications $^{3}$ & 2 & 3 & 1 & 2 \\
\hline
\end{tabular}

Source: Author's elaboration based on Caprio and Klingebiel (2003), Demirgüç-Kunt and Detragiache, Lindgren, Garcia and Saal (1996) and Kaminsky and Reinhart (1999). The column of 'Concept used' identifies the concepts explicitly stated to define crisis or similar events in each work. A ' $\mathrm{C}$ ' indicates 'qualitative' reference to the concept, a ' $\mathrm{Q}$ ' indicates a quantitative reference to the concept. (1) Includes mergers, takeovers, interventions and closures. (2) Refers to economic assistances and (3) refers to the types of episodes (systemic, nonsystemic, etc)

Two aspects are worth noting from the above definitions and Table II.1: first, either directly or indirectly (see Box 2), these definitions heavily rely on government actions to identify problems. Secondly, all of them leave plenty of room for personal judgment.

Relying on government interventions offers some pros and cons. Since the nature of the financial system is highly complex and involves many variables, it is hard to establish and measure a counterfactual benchmark situation to assess whether it has significantly departure from that standard. Thus, observing the appearance of extraordinary -negativeevents seems to be an acceptable method to get around this natural complexity. On the other hand, government interventions may be significantly delayed for several reasons, including simply failure to recognize the outset of problems, political reasons to delay reforms, regulatory forbearance, implementation problems and many others.

The second characteristic aspect of these empirical definitions is ambiguity. The four definitions are actually stated quite differently; however, as a rule, these definitions avoid making detailed quantitative and conceptual specifications, leaving enough freedom at the stage of its empirical implementation. This lack of precision and ambiguity is precisely the way definitions allow for personal judgment come into play. This 'personal judgment' is what ultimately defines what constitutes a bank run, when there exists a 'substantial' portfolio shift, the moment at which government intervention leaves normal stances, becomes 'massive' and reaches its peak, how problems are classified between systemic and non-systemic, whether problems have -or not- a significant impact on either the functioning of the banking sector as a whole or the macroeconomy, and other additional aspects. However, this ambiguity -particularly in the above definitions- is not the 
consequence of loose definitions; instead, it is almost an 'optimal' response provided the complexity of the issue under consideration.

Naturally, there exist some other chronologies besides those presented so far. ${ }^{8}$ However, instead of persisting on the exploration of its definitions and concepts, the next paragraphs in point II.B proceed with a short, and rather quantitative, description and comparison of those commonly cited datasets.

\section{Box 1: Selected Theoretical Descriptions of Financial Instability}

The following are anything but a few analytical definitions of financial instability intended to exemplify their diversity, reflecting different judgments on the problem.

- Anna Schwartz (1986). A financial crisis is fueled by fears that the means of payment will be unobtainable at any price and, in a fractional reserve banking system, leads to a scramble for high-powered money. It is precipitated by actions of the public that suddenly squeeze the reserves of the banking system.... The essence of a financial crisis is that it is short-lived, ending with a slackening of the public's demand for additional currency.

- Frederick Mishkin (2000). A financial crisis is a disruption to financial markets in which adverse selection and moral hazard problems become much worse, so that financial markets are unable to efficiently channel funds to those who have the most productive investment opportunities.

- Roger Ferguson (2000). In my view, the most useful concept of financial instability for central banks and other authorities involves some notion of market failure or externalities (...) such as moral hazard and asymmetric information that, if widespread and significant, can result in threats to the functioning of any financial system, such as panics, bank runs, asset price bubbles, excessive leverage, and inadequate risk management. (...) Thus, (...) I'll define financial instability as a situation characterized by these three basic criteria: (1) some important set of financial asset prices seem to have diverged sharply from fundamentals; and/or (2) market functioning and credit availability, domestically and perhaps internationally, have been significantly distorted; with the result that (3) aggregate spending deviates (or is likely to deviate) significantly, either above or below, from the economy's ability to produce. (...) central banks can alter monetary policy to forestall or mitigate the consequences of financial instability for the economy $(. .$.$) when such instability slides into crisis.$

- Andrew Crockett (1997). (...) instability (..) is a situation in which economic performance is potentially impaired by fluctuations in the price of financial assets or by an inability of financial institutions to meet their contractual obligations. (...) my definition refers to the price of financial assets as well as to the position of financial institutions. In other words it refers not just to banks but to non-banks, and to markets as well as to institutions.

- John Chant (2003). Financial instability refers to conditions in financial markets that harm, or threaten to harm, an economy's performance through their impact on the

\footnotetext{
8 Among them, Eichengreen and Bordo (2002) and Schwartz y Bordo (2000) could be mentioned.
} 
working of the financial system. (...) A financial crisis is an extreme degree of financial instability, where the pressures on the financial system are sufficient to impair its function significantly over a prolonged period. But financial systems can be subject to stress well before a crisis takes hold.

- Mark Illing and Ying Liu (2003). Financial stress is defined as the force exerted on economic agents by uncertainty and changing expectations of loss in financial markets and institutions. Financial stress is a continuum (...) where extreme values are called financial crises.

- Group of Ten (2001). A financial crisis is the occurrence of a systemic event in the financial system that will trigger a loss in economic value or confidence in a substantial portion of the financial system that is serious enough to . . . have significant adverse effects on the real economy.

\section{Box 2: Different Empirical Definitions of Crisis? The ‘Hidden’ Link}

The case presented with DK-D is useful to highlight a key point. These authors initially merged different datasets into one list of banking distress from which they select 'fullfledged' crises. Such procedure implicitly suggests that those seminal different datasets are rather independent from each other. However, a bibliographical inspection quickly reveals that sources of information are closely intertwined: LGS uses Sheng (1996), Caprio and Klingebiel (1996), Sundararajan and Baliño (1991) and various official and newspapers; CK uses Lindgren, Garcia and Saal (1996), Sheng (1996), Sundararajan and Baliño (1991) and Caprio and Klingebiel (1996); and KR uses Caprio and Klingebiel (1996) and Sundararajan and Baliño (1991). Even though this 'hidden' link among datasets by no means establishes a direct and linear relationship among them, it should be kept in mind.

Going back to the DK-D definition, this consideration makes explicit the fact that, even after applying additional criteria, the resulting chronology finally inherits part of the ambiguity of its sources. This feature is also mentioned by Eichengreen and Arteta (2000). These authors estimate in 0.92 the correlation between crisis dates in the surveys of Glick and Hutchinson (1999) and of Caprio and Klingebiel (1999) and consider this an expected outcome since $\mathrm{GH}$ draws on $\mathrm{CK}$. 


\section{II.B. Some Quantitative Comparisons}

One important aspect to consider when comparing different surveys of banking problems is their temporal and geographical coverage. Unfortunately, this aspect is not always completely clear, rising doubts on the reasons behind the exclusion of a certain period as a crisis period. Table II.2 presents some coverage summary figures for CK, LGS and KR.

Table II.2 Coverage Summary of CK, LGS and KR

\begin{tabular}{lccc}
\hline \hline & CK & LGS & KR \\
\hline Time coverage & & & \\
Explicit country coverage & Late 1970s-2002 & $1980-1996$ & $1970-1997$ \\
$\quad$ of which: countries with episodes & 123 & 181 & 20 \\
Number of Episodes & 123 & 140 & 20 \\
$\quad$ of which: episodes with definite dates & 168 & 156 & 30 \\
& 125 & 134 & - \\
\hline
\end{tabular}

Source: Author's elaboration based on Caprio and Klingebiel (2003), Lindgren, Garcia and Saal (1996) and Kaminsky and Reinhart (1999). Time coverage refers to the period covered by the studies. Explicit country coverage indicates that is possible to identify as included in the sample. The number of episodes indicates the total number of episodes (including crises, secondary problems and other categories). Definite dates refers to those cases that have attached clear dates (that is, avoid expressions such as 'ongoing', 'mid-19XXs', 'several instances' and similar). (1) Includes out of sample cases

\section{An example of differences: building a new dataset}

Sometimes a list of crises is built by assembling datasets from different sources -as in the case of Demirgüç-Kunt and Detriagiache (1998). This section presents an example based on a similar procedure. The aim of this example is to highlight some discrepancies among various datasets and call the attention over potential problems related to the process of merging datasets. ${ }^{9}$ The example is restricted to those countries and periods simultaneously covered by the studies of LGS, CK and KR and thus consists of a reduced sample constituted by the KR's countries and LGS's years.

Demirgüç-Kunt and Detragiache did not merge datasets without restriction, but imposed at least an additional quantitative criterion to select 'full-fledged crises'. Similarly, in this example, datasets will be merged using an additional criterion. Three alternative reasonable criteria are considered -and actually applied- to merge datasets; these are arbitrarily named extensive, intermediate and narrow criterion. The first one signals the presence of problems wherever some dataset identifies at least significant problems -including nonsystemic or significant problems. The second alternative recognizes the presence of a crisis if at least some dataset does. ${ }^{10}$ Finally, the third criterion spots a crisis if and only if everyone agrees on the presence of systemic problems. After applying these criteria, three new datasets were obtained.

Comparison of these new and old datasets renders some insightful results, related to the number of episodes, their average duration and the time pattern of discrepancies between datasets.

\footnotetext{
${ }^{9}$ This section is not intended as a critic to the studies of Lindgren, Garcia and Saal, Caprio and Klingebiel and Kaminsky and Reinhart. It just attempts to highlight some discrepancies and problems derived from its oblivious use.

${ }^{10}$ Notice that the first criterion considers significant problems, while the second points to crises.
} 
Number of crises, average duration and other differences between CK, LGS and KR

Table II.3 shows how, even when considering a rather small sample of well-known and studied countries and a relatively recent period, differences easily emerge.

Depending on the study, full-fledged crises initially vary from 21 to 25 . Average numbers blur differences a little bit. For instance, considering only CK and LGS, a more detailed inspection reveals that both identify 5 cases of significant (nonsystemic) problems but only agree on 3 of them. Moreover, two times CK called an episode as systemic at the same time LGS deemed it only as significant (in one case is the other way around) and in 2 cases an episode is not acknowledged by the other - under any classification. Differences extend more when considering complete agreement: without reference to duration, agreement on the number of crisis rises to 19 when considering only CK and LGS, and to 17 when KR is also considered.

\section{The narrow criterion as the consensus view}

The last three columns in Table II.3 shows how differences among original dataset may translate into different final datasets, depending on the selected criteria to merge them. Though all three constructed datasets may be deemed as reasonable, one clearly stands out: the one built under the narrow criterion (the one requiring marking a crisis if and only if all three studies agree on the presence of a full-fledged crisis). A dataset assembled under this criterion may be deemed -to some extent- as representing the consensus view and counts 17 crises -a number clearly below the range of 21-25 crises established by the original lists. It is important to notice that any of these datasets -originals and merged- would be admissible to perform a study on banking crisis. However, results will probably differ whether the number of crises considered is 17 or it is increased almost $50 \%$ to the 25 cases of $\mathrm{KR} .^{11}$

\section{Table II.3: Summary Comparison of KR, LGS, CK and Merged Dataset}

\begin{tabular}{|c|c|c|c|c|c|c|}
\hline & \multirow[t]{3}{*}{ LGS } & \multirow[t]{3}{*}{$\mathrm{CK}$} & \multirow[t]{3}{*}{ KR } & \multicolumn{3}{|c|}{ Merged dataset } \\
\hline & & & & \multicolumn{3}{|c|}{ Alternative Criteria } \\
\hline & & & & Extensive & Intermediate & Narrow \\
\hline Total episodes & 26 & 28 & 25 & 29 & 27 & 17 \\
\hline Crises & 21 & 23 & 25 & & & \\
\hline Significant problems & 5 & 5 & & & & \\
\hline Average length (years) & 4.4 & 4.8 & & 5.4 & 5.3 & 3.9 \\
\hline
\end{tabular}

Sources: Author's calculations based on Caprio and Klingebiel (2003), Lindgren, Garcia and Saal (1996) and Kaminsky and Reinhart (1999). The extensive criterion signals the presence of problems wherever some dataset identifies at least significant problems (that is, at least nonsystemic or significant problems). The intermediate criterion recognizes the presence of a crisis if at least some dataset does. Finally, the narrow criterion spots a crisis if and only if everyone agree on the presence of systemic problems. The sample includes KR's countries during 1980-1996 (LGS's coverage period)

\section{The time pattern of differences}

As shown, merging datasets using alternative criteria may lead to different results. An interesting point to note is that eventual differences in outcomes may also vary in time.

${ }^{11}$ Not only the number of crises differ, but also its average duration. Differences among dataset broaden even more when the two additional criteria are considered. 
This is shown in Figure II.1, which This figure plots the fraction of the sample classified as experiencing an episode of banking distress on each year between 1980 and 1996. ${ }^{12}$ The figure shows that both the extensive and the intermediate criteria deliver similar results; it also shows that differences between the narrow criterion and the other two do not evolve uniformly, meaning that discrepancies between classifications in the original datasets vary in time. ${ }^{13}$ Regarding these differences, it is worth noting how the moment of highest financial turbulence in the sample can change under different assumptions: if the narrow criterion is followed, then the moment of highest turbulence is 1982, but if any of the two alternative criteria applies then 1985 becomes the peak-year

\section{Figure II.1. The Evolution of Financial Problems Under Alternative Criteria.}

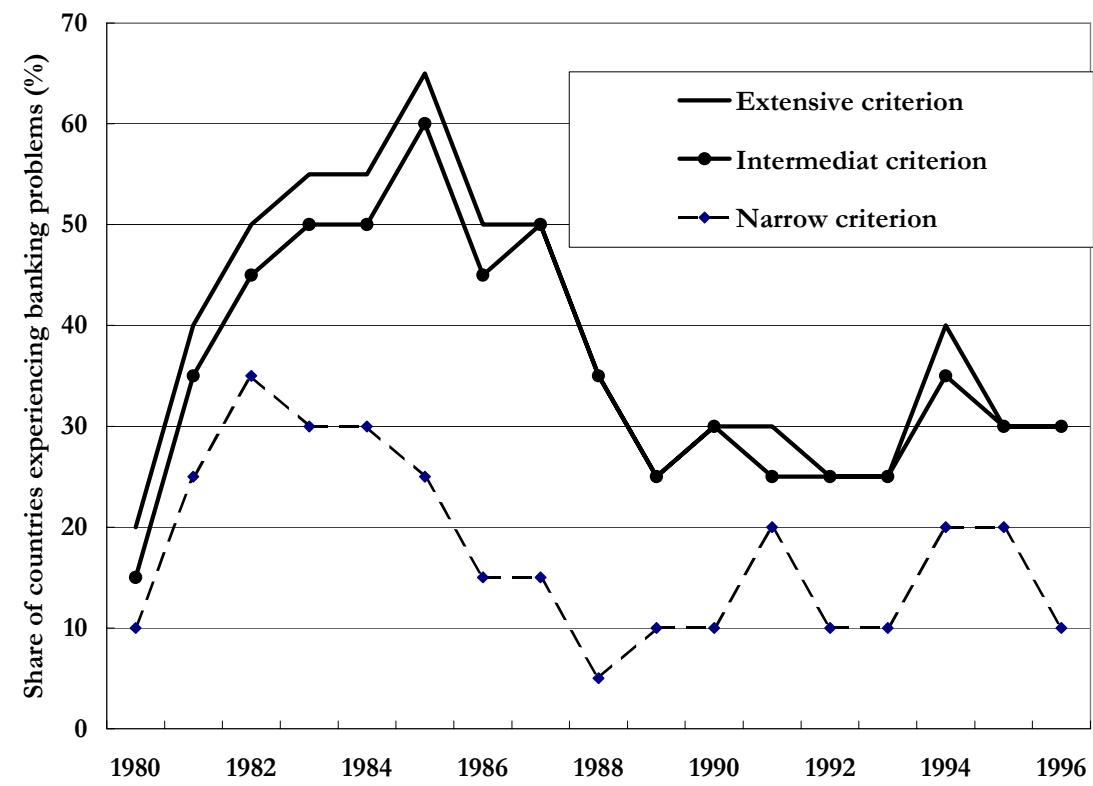

Source: Author's calculations based on Caprio and Klingebiel (2003), Lindgren, Garcia and Saal (1996) and Kaminsky and Reinhart (1999).

Each line depicts the share of countries experiencing banking problems under alternative aggregation criteria. The sample countries are: Argentina, Bolivia, Brazil, Chile, Colombia, Denmark, Finland, Indonesia, Israel, Malaysia, Mexico, Norway, Peru, Philippines, Spain, Sweden, Thailand, Turkey and Uruguay. The sample period covers 1980-1996. The extensive criterion signals the presence of problems wherever some dataset identifies at least significant problems (that is, at least nonsystemic or significant problems). The intermediate criterion recognizes the presence of a crisis if at least some dataset does. Finally, the narrow criterion spots a crisis if and only if everyone agree on the presence of systemic problems.

\section{Box 4: The Onset of Crises and Duration: Impact on EWMs and Estimated Costs}

It is also instructive to highlight some remarkable discrepancies on case-specific basis, each one representing a usual divergence between alternative studies. Two cases are considered: Argentina (onset of crises) and Mexico (duration).

In the case of Argentina, both LGS and CK agree to date the beginning of a crisis in 1989, but KR consider that this episode began 4 years earlier, suggesting either that LGS and CK fail to recognize the problems during 4 years or that $\mathrm{KR}$ falsely signal a crisis 4 years earlier

12 Each line depicts the share of countries experiencing banking problems under alternative aggregation criteria (the extensive, intermediate and narrow criteria defined above).

${ }^{13}$ In other words, differences are not rooted in systematic discrepancies between classifications in the original datasets. The mild difference between the extensive and intermediate criteria is due to the relative scarcity of nonsystemic problems in the classifications. 
than it actually happened. This type of discrepancies is indeed quite common and, clearly, impact on the results obtained -for instance- in early warning models.

The second case refers to Mexico and focus on the length of crises. According to LGS, this country experienced a crisis in 1982 that ended the next year. CK also consider 1982 as a crisis year, but they judge this crisis as persisting during 11 years. Even though smaller, this type of discrepancy is also quite usual among different dataset, and may affect -for instance- the results of studies focusing on the relationship between the length and cost of banking crisis.

\section{Bottom line}

First, it is very important to remark that this section and its examples attempt by no means discredit the studies of LGS, CK and KR, which are outstanding pieces of research. Rather, the purpose of this section is draw the attention two issues: the potential consequences of merging datasets and, more importantly, the presence of discrepancies among alternative chronologies of banking problems.

As regards the process of merging datasets from different authors, this section advocates to carefully perform this process, trying to identify all the implicit or explicit assumptions involved, including those already contained in the source datasets.

More important, this section claims that identification of financial problems is not a closed case. The example showed that even considering a sample of extensively studied countries discrepancies might still be large. Discrepancies may stem from different sources, such alternative definitions and subjective judgment -and their interaction. However, whichever the reasons behind discrepancies, the flat fact is there: so far, there is no an undisputed chronology of banking crisis. Therefore, several alternatives are plausible or acceptable.

\section{An Alternative Procedure to Date Banking Problems}

The event approach, usually followed by the different studies to empirically define the presence of banking problems, is supported by the appealing idea that emergence of abnormal events signals the presence of abnormal situations and has the advantage that some of the events used to identify the presence of problems are, at least in principle, very easy to identify. However, as a rule, an exact definition of these events is not provided. This methodological and quantitative ambiguity in the identification of events combines with the use of 'restricted' or vaguely identified sources to produce an undesirable outcome: chronologies that are quite difficult to replicate independently.

This section is devoted to present an alternative to this procedure. It first reviews the method usually followed to identify balance-of-payments problem, claiming that three reasons supports its extensive use: theoretical foundations, data availability and replicability. Then, trying to follow such rules, the next part proposes a composite index to identify the presence of banking problems. 
An alternative approach in other studies: the index of currency market turbulence

One aspect distinguishing empirical studies on balance-of-payments problems from those on banking problems is that the former presents a clearer and relatively wide-accepted approach to identify crises. In short, the procedure attempts to identify large realizations of a continuous index, which in its simpler form is nothing but the rate of change of the exchange rate. However, the most extended version comprises also the rate of change of foreign reserves. ${ }^{14}$ More precisely, this latter version takes the following form:

$I C M T=\frac{1}{\sigma_{e}} \cdot \frac{\Delta e}{e}-\frac{1}{\sigma_{R}} \cdot \frac{\Delta R}{R}$

In this index of currency market turbulence, $\Delta e / e$ stands for the rate of change of the exchange rate, $\Delta R / R$ for the rate of change in reserves and $\sigma_{e}, \sigma_{R}$ are the corresponding sample volatilities (standard deviations).

There are three reasons supporting the extensive use of this index of currency market turbulence. One is that, in spite of developments in the theory on the causes of balance-ofpayments problems, interest remains focused on explaining sharp changes in exchange rates (and foreign reserves); in other words, there is a large agreement on the variables that should be observed to state the presence of problems. A second and important reason is that these 'variables of interest' are clearly and accurately measured and publicly available. Finally, also contributing to its widespread use, the reported chronologies based on this index are easily verifiable and, more important, may be applied to almost any country and period.

\section{An alternative to identify banking problems: a Financial Stress Index}

Clearly, the empirical literature on banking crises lacks of a parsimonious and widely accepted index such the index of currency market turbulence (ICMT) described above (equation III.1). ${ }^{15}$ This work attempts to move towards this direction trying to propose a parsimonious index composed by extensively reported and easy-to-access variables. Specify a financial stress index (FSI) along the lines of the ICMT's highlighted characteristics, requires following a three-stage procedure: (i) provide a definition of financial crisis, (ii) identify the statistical series that accommodate to that definition, and (iii) present a concrete specification

\section{Box 5: Some Indexes of Financial Stress}

The attempt to identify banking problems using a (financial stress) index is not a new idea. This Box reviews the indexes proposed by Bordo, Dueker, and Wheelock (2000) and Illing and Liu (2003). It also presents two non-academic indexes proposed by the Bank Credit Analyst (BCA) and JP Morgan.

\footnotetext{
14 There is also a third version of this index that additionally includes interest rates. However, its use is less extended since for many developing countries long series on interest rates are hard to obtain.

15 Some indexes proposed to identify and 'measure' financial stress are described in Box 5.
} 
Bordo, Dueker, and Wheelock (2000) propose a Quantitative Index of Financial Conditions to identify episodes of financial instability in the United States between 1870 and 1997. This index includes yearly data on: (i) bank failures, (ii) non-financial business bankruptcies, (iii) an ex post real interest rate, and (iv) an interest rate quality spread. These variables are use to form a composite index in the following form:

$I_{t}=\sum_{j=1}^{J} \frac{\left|x_{t}^{j}-x^{j}\right|}{\hat{\sigma}_{a, b}}$,

where for each variable $x^{j}$ is computed the distance between each observation and the median for that variable. Distances for those observations that are below the median are divided by the standard deviation of a series consisting of all observations below the median and an equal number of generated observations of equal distances above the median. Similarly, distances for observations that are above the median are divided by the standard deviation of a series consisting of all observations above the median and an equal number of generated observations of equal distance below the median. The generated observations are then discarded, leaving a series of observations for each variable consisting of standardized distances from the median. Then, overall mean and standard deviation is calculated and each observation is classified into one of five categories. Particularly, realizations of this index falling 1.5 standard deviations above the mean are classified into the "severe stress" category.

In turn, Illing and Liu (2003) follow a different approach and a quite different set of variables to propose a composite Index of Financial Stress for Canada. The authors followed an approach that very much resembles the usual procedures in the early warning literature. First, they establish a ranking of stressful events for the Canadian financial system through an internal Bank of Canada survey. Then, they use this ranking to condition the choice of variables and to evaluate their ability to reflect the responses to the survey regarding highly stressful financial events. In this case, The variables included in the index were daily measures of relative equity-return volatility, banking sector bond yield spread, corporate bond risk, covered interest rate spread, inverted yield curve, undervalued currency, equity-risk premium and commercial paper spread and were combined under alternative weighting schemes.

Indexes proposed by BDW e IL exhibit a particularly desirable characteristic of the ICMT in III.1. Since both describe procedures and sources in a rather careful way, their results can be replicated or extended to cover additional periods or -to the extent of possibleother countries. However, since the variables used are not available for a large set of countries over extended periods, its use to identify crises in samples such as those of LGS and $\mathrm{CK}$ or even $\mathrm{KR}$ is quite dampened.

Outside academics, alternative indexes have also been proposed. The Bank Credit Analyst (BCA) produces a Financial Stress Index for the United States that includes the performance of major U.S. banks' share prices relative to the overall market, short- and long-term quality credit spreads, private sector indebtedness, stock market leverage (corporate debt to cash-flow), overall stock market performance, consumer confidence, the slope of the yield curve, and stock and bond issuance. Similarly, JP Morgan produces a daily Liquidity, Credit and Volatility Index (LCVI) that contains seven components: the U.S. Treasury curve error (rolling standard deviation of the spread between on-the-run and off-the-run U.S. treasury bills and bonds along the entire maturity curve), the 10-year U.S. swap spread, JP Morgan's Emerging Markets Bond Index (EMBI+), U.S. high-yield spreads, foreign exchange volatility (weighted average of 12-month implied volatilities of each of the euro, yen, Swiss franc, U.K. pound, Canadian dollar, and Australian dollar 
expressed in U.S. dollars and weighted by daily turnover.), the Chicago Board of Exchange equity volatility index VIX, and the JP Morgan Global Risk Appetite Index. Needless to say that these indexes can only be computed for the United States and a few more countries.

\section{What is a financial crisis? ${ }^{16}$}

The financial system is a complex structure. In general terms, it helps in the allocation of available resources between alternative and competitive opportunities. Moreover, since resources are scarce, it is desirable and expected that this system allocate these available funds into the most useful opportunities.

Roughly speaking, four types of agents participate in this system: lenders, financial intermediaries, regulatory bodies and borrowers. This classification involves four types of participants, and not only a simple dichotomic separation between lenders and borrowers mainly due to one important particular characteristic of financial markets, namely asymmetric information. Both financial intermediaries and central banks are usually seen playing important roles in mitigating the consequences generated by information based market failures. ${ }^{17}$

Asymmetric information generates two types of problems: adverse selection and moral hazard. These problems negatively affect the financial system's ability to allocate the available funds to the most useful opportunities and, the more acute these problems become the less efficiently the financial system performs. In some cases, these problems become so intense that the system is deemed as experiencing a quite abnormal situation. In this line of reasoning, Mishkin (2000) provides a definition of what a financial crisis is:

"A financial crisis is a disruption to financial markets in which adverse selection and moral hazard problems become much worse, so that financial markets are unable to efficiently channel funds to those who have the most productive investment opportunities".

\section{Identifying potential components for the FSI}

To attain a working measure relating to the previous theoretical definition it is useful to expose a simple an operative definition of what a bank is: a bank is an institution whose current operations consists in granting loans and receiving deposits from the public. ${ }^{18}$ This definition could be easily related to Mishkin's definition, linking the evolution of informational problems to the evolution of loans and deposits. More precisely, this association will be assumed a negative one, considering that increased informational problems negatively affect the evolution of deposits and loans -and the more severe asymmetric information becomes the more restrained the evolution of deposits and loans become.

Therefore, these two concepts -loans and deposits- will be crucial to compound the proposed index. However, besides these two concepts, current institutional arrangements implemented in almost every country suggest the inclusion of one additional concept, namely credit from the monetary authority, since governments actively intervene in the

\footnotetext{
16 This section attempts to sketch a definition to select those variables that will be incorporated into the composite index. A theoretical review of financial crises or the functioning of the financial system it is outside its purpose.

17 Clearly, asymmetric information is not the only reason that explains the existence of banks and central banks. See Freixas and Rochet (1999).

${ }^{18}$ Freixas and Rochet (1999).
} 
banking system and central banks are among the most extensively used instrument. ${ }^{19}$ Consequently, this kind of government intervention will also be included in the index (for a slightly more detailed description of interactions between asymmetric information and loans, deposits and government intervention see Box 6). ${ }^{20}$

Thus far, this rather intuitive argumentation suggests three variables to include in the FSI, namely private bank deposits, bank credit to private sector and credit from the monetary authorities to bank institutions. ${ }^{21} 22$

\section{Box 6: Asymmetric information, deposits, loans and liquidity support}

One feature distinguishing financial markets from other markets is the presence of significant asymmetric information problems. ${ }^{23}$ These informational asymmetries translate into adverse selection and moral hazard problems. Adverse selection refers to a diminished capacity to discriminate between different types of agents within a specified class -for instance sound or unsound banks or good and bad credit risks. Moral hazard develops subsequent to the signing of a contract or engagement in a relationship. ${ }^{24}$ Both these problems hamper the ability of financial markets to efficiently channel available funds from those who have it to those with the most productive opportunities. These shortcomings in the flow of funds may originate mostly during the seizing of funds or its placement. In other words, problems may emerge because banks cannot seize enough deposits and/or because they refrain from lending.

Banks may experience troubles to receive or keep deposits owing to fundamental or informational problems. The former case refers to situations where banks' balance sheets 'describing' its fundamental situation- has deteriorated and therefore face problems to collect and maintain deposits. The latter case refers to instances where a coordination failure among depositors emerges and begins a fast withdrawal of funds (Diamond and Dybvig, 1983). This coordination failure is rooted in asymmetric information and can be triggered by several factors, such as interest rates hikes -if are considered by the public as part of a 'gambling for resurrection'- or policy uncertainty. Either if bank runs are fundamental-based or 'irrational', due to asymmetric information they can evolve into bank panics and thus jeopardize the system stability.

In turn, asymmetric information may also affect the evolution of loans. In this regard, there exist two obstacles banks should overcome in the process of granting loans, namely adverse selection and moral hazard. That is, banks have to devote resources to not only select the most adequate candidates for a loan but also have to select and implement the most adequate monitoring and enforcement strategies once the credit is granted. The harder these problems to overcome, the less incentives to grant a loan. Again, as in the case

${ }^{19}$ A concise review of justifications for banking regulation and particularly of central banks can be found in Freixas and Rochet, 1999.

${ }^{20}$ There is an additional reason favoring the use of these three concepts: contrary to other financial variables (see Box 5), these concepts are extensively reported and its availability extends to numerous countries, during extensive periods on a monthly basis.

21 The distinction between public and private deposits and credit is important since the government is confronted with a different set of restrictions and objectives.

22 A detailed explanation of sources and definitions is provided in Annex I.

${ }^{23}$ Asymmetric information is said to be present when one of the parties involved in a transaction has better relevant information than the other(s) and uses it a their expenses.

24 With one party hiding information or activities 
of deposits, several factors may increase informational problems -including deteriorated nonfinancial balance sheets, increased interest rates and increased uncertainty. ${ }^{25}$

An additional feature that should be considered is central bank intervention. As stated above, banks are subjected to the chance of runs -either fundamental based of 'irrational'. When such events take place, a possible response to avoid potential harmful consequences takes the form of liquidity support -particularly to troubled institutions. Therefore, a sharp and/or significant increase in liquidity support may be deemed as a signal marking the presence of adverse selection problems. However, this solution may induce an undesirable side effect since it can exacerbate moral hazard (increasing the incentives for excessive risktaking on the part of the banks). Thus, is important to note that liquidity support may be associated to both types of problems, but over distinct horizons. Increased liquidity support to assist troubled institutions to avoid contagion signals the presence of adverse selection problems during the period surrounding the assistance. At the same time, this provision and its maintenance would increase future moral hazard problems.

At this point two remarks are worth noting. First, the proposed index is not intended to be an EWS. The second remark is a little bit longer. It points to the possibility to provide alternative interpretations for each index component depending on the period length under consideration. For instance, a contraction of private deposits will drive the index down. However, a private deposit slowdown -that is, a reduced deposit growth rate- will also put a downward pressure over the composite index. While the former movement may well be deemed as a reflection of increased adverse selection problems, the latter may respond mostly to quite different factors. A similar case may be made for loans granted to the private sector. A relatively diminished credit growth rate will tend to put -again- a - usually smooth- downward pressure over the final index. Instead, an outright 'credit-crunch' will tend to have sharper influence on the index. Again, while the latter case may be mostly influenced by asymmetric information problems, the former may respond to many additional factors. The credit from the monetary authority will also affect the evolution of the composite index. A steady relative increase of liquidity support will tend to drive the index down. This process may endure in time and may not necessarily be a response to coordination failures among depositors. Instead, if a bank run emerges the central bank may quickly respond providing all the required assistance to troubled institutions and prevent contagion. In this latter case, the FSI will be quickly pushed down and adverse selection may be blamed (instead the former policy may bear little relation with these type of problems). ${ }^{26}$ All these considerations should be kept in mind when considering the evolution of the FSI. Informational problems may well be important forces affecting the evolution of deposits, loans and central bank assistance. However, many other factors may also influence the evolution of these variables - such as regulatory changes, financial innovations, macroeconomic developments and many others- and therefore will have an effect on the FSI evolution.

\section{Additional transformations, weighting scheme and functional form}

Once defined the concepts to consider, three additional issues remain in order to specify the composite index: previous data 'transformation', selection of a weighting scheme and the choice of a functional form.

25

${ }^{26}$ However, such policy may induce future problems due to moral hazard problems. 
Considering the first of these issues, it is instructive to note the way nominal reserves and exchange rates enter the index of currency market turbulence (equation III.1). This index actually uses changes in nominal exchange rates and nominal reserves instead of their level. This is primarily due to the positive time trend exhibited by these variables. ${ }^{27}$ Provided loans, deposits and -to lesser extent- central bank assistance present an analogous time trend than exchange rates and reserves, a similar transformation may be advised. ${ }^{28}$ However, in the present case the series will not be transformed in the same way as in the ICMT. This transformation is avoided for two reasons. One is preventing from the need to treat separately countries that experienced episodes of high inflation or outright hyperinflation. ${ }^{29}$ The second -and more important- reason is to retain the possibility to use the index to identify not only the onset of an episode but also its end. Thus, instead of use variations (and after analyzing several alternatives), it was decided to incorporate the variables as measured by their participation in banks' balance sheets. More precisely, the FSI will be composed by: the share of private deposits in banks' liabilities (rel_dth), the share of credit to the private sector in banks' assets (rel_pra) and the share of banks' liabilities constituted in the form of credit from the monetary authorities (rel_bcl). These 'transformations' offer the advantage of eliminating the need of differentiate treatment conditional on inflationary processes. Besides, they provide some intuitive support to use the FSI to establish the end of a crisis episode based on the appealing idea that these magnitudes tend to revert to some 'optimal' or 'adequate' level after the shock has dissipated. ${ }^{30}$

As regard the second issue, selected weighting scheme is highly standard. Weights are defined as the inverses of each series' sample volatility. This design precludes that one series 'dominates' the others and from there the evolution of the final index. Roughly speaking, this weighting scheme implies that all three concepts are equally important for the evolution of the index.

Finally, a simple and traditional additive functional form is selected to combine the series. In particular, in line with the previous comments and discussions, the variables rel_dtl and rel_pra enter with a positive sign and rel_bcl with a negative one (arbitrarily the index is 'designed' to fall as problems or pressure increase).

Then, proposed FSI takes the following form:

$$
F S I_{1}=\frac{r e l_{-} d t l}{\sigma_{r e l_{-} d t l}}+\frac{r e l_{-} p r a}{\sigma_{r e l_{-} p r a}}-\frac{r e l_{\_} b c l}{\sigma_{r e l} b c l}
$$

where the $\sigma_{x}$ are the corresponding sample volatilities (standard deviations) and the terms are signed according to the previous discussion.

Additionally, for those cases where missing data, aggregation problems or other reasons precludes the use of III.2, an alternative FSI is provided. This index replaces rel_pra by the share of private credit in domestic credit (rel_cred) and rel_dtl by the M2 multiplier (mm2): ${ }^{31}$

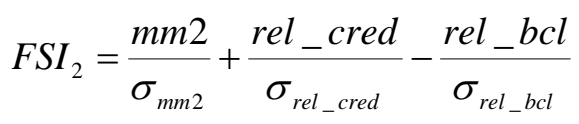

\footnotetext{
27 This positive trend is particularly acute in nominal exchange rates in high inflation countries.

28 The case of central bank assistance presents particular characteristics.

${ }^{29}$ This separation is effectively conducted to identify balance-of-payments crises using the ICMT.

${ }^{30}$ Two important remarks: (i) these are nothing but intuitive notions and (ii) even if they exist, these 'optimal' levels may be time varying.

${ }^{31}$ Roughly speaking, rel_cred is simply a broader measure than rel_pra. The M2 multiplier presents a slightly different case but it may also be deemed as a relative measure of deposits.
} 
where again the $\sigma_{x}$ correspond to the sample volatilities (standard deviations) of each concept.

Additionally, a third alternative that excludes rel_bcl is considered for those cases were this information is missing.

\section{Applications}

This section presents three applications of the FSI. The first compares the evolutions of the FSI with the chronologies presented by CK, LGS and KR on four cases: Argentina, Brazil, Chile and Mexico. The second application is inspired in the literature of twin crises and compares the evolution of the FSI the real exchange rate and an alternative measure of currency market turbulence. Finally, the FSI is applied on a sample of 42 countries to obtain an alternative chronology of banking problems.

\section{Application 1: Comparing the FSI with the chronologies of CK, LGS and KR}

As mentioned in section II, empirical studies involving banking crises usually rely on previous studies to identify episodes of banking problems. ${ }^{32}$ Among the usually cited studies are those extensively referred throughout this work, namely CK, LGS and KR. This widespread use is largely a consequence of the complexity of dating banking problems, but also reveals a relatively high acceptance of its proposed chronologies. Thus, it turns out to be natural check the ability of the proposed FSI to reflect the presence of highly stressful events as dictated by these previous studies -particularly during episodes of high consensus -such as the Tequila crisis or the more recent episode in Argentina during the early-2000s. However, it is also of interest to explore those situations where the FSI suggests a period of increased stress but previous studies remain silent. These comparisons were effectively performed with every country considered in the survey provided in Annex I. However, for the sake of simplicity, this application concentrates only in a few Latin American cases.

Thus, this part compares for some selected countries the FSI formulated in III.2 with the classifications of CK, LGS and KR. It also presents the evolution of the alternative index (equation III.3) in order to highlight the possibility of its use as an acceptable substitute. ${ }^{33}$ Figures IV.1 - IV.4 present the evolution of proposed FSIs for the cases of Argentina, Brazil, Chile and Mexico. In this figures, light-shaded regions indicate periods where at least one of the three works points the presence of financial problems; instead, dark-shaded regions cover periods where all three works agree on the presence of financial problems. ${ }^{34}$ 35

\footnotetext{
32 Either using banking problems as a dependent or independent variable.

${ }^{33}$ It should be clear that the first FSI is preferred to the second; both indexes are presented simultaneously to stress the fact that both performs similarly, and so use the second specification it is valid alternative for those cases where missing data, aggregation problems or other reasons precludes the use of the first one.

34 As stated earlier in section II, common coverage of these studies ranges from 1980 until 1996. KR report only the time between the beginning and the peak of the crises

35 A more detailed description of relevant events surrounding the crises identified in these examples is presented in the corresponding cases presented in the listed in Annex I.
} 
Argentina

Figure IV.1 presents the case of Argentina. The first shaded region covers the years 19801982, a period where the three studies -that is, LGS, KR and CK-identify financial problems. During this period, many institutions were closed or intervened and nonperforming loans began to rise. As regards the FSI, it is clear that it initiates a downward movement during the early months of 1980 and it shows a sharp drop by mid 1982 -very close to the peak month identified by KR.

The second shaded region begins in 1985. KR mark the beginning of a new crisis in May 1985 and its peak in June 1989. Once again, there is agreement between these dates and those in which the FSIs display substantial changes. However, both CK and LGS do not explicitly acknowledge the presence of a crisis until the period 1989-1990. As a measure of extent, during this period, nonperforming loan rose and many banks failed.

A third shaded area begins in 1994, more precisely in December 1994. This date, signaled by KR, again fits closely with the beginning of a contraction of the FSIs. In this case the three studies agree on the short duration of this crisis that lead to the closure and merge of many institutions.

The fourth and final area is only reported by CK. According to these authors, the crisis erupted in 2001. This date may also be considered as the beginning of a retrenchment of the FSI, which displays a renewed and sharper contraction in November 2001 -date in which partial withdrawal restrictions on deposits were imposed.

Brazil

In this case, the first shaded region derives from $K R$, since it is a tranquil period for LGS and CK with reference to financial problems. Attached date is November 1985 (pointing both the beginning and the peak of the crisis) and accurately agrees with a sharp fall in the FSI. In this case, it is worth noting one again that KR do not date the end of financial crises.

The second shaded area derives from CK and covers 1990. Here, the FSI display a sharp decline in proximate dates -even though the beginning of the contraction could be traced back to mid 1989.

The third shaded section begins in 1994 (LGS and CK). KR identify November 1994 as the beginning date of the crisis and according the CK this episode ended in 1999

Chile

Figure IV.3 presents the evolution of the FSI for the case of Chile. The first shaded region corresponds to 1976 (CK). Unfortunately, in this case, missing data precluded the computation of any FSI.

The second shaded region covers the period 1981-1987. In this case, the FSI displays a deep and protracted contraction fitting closely with the shaded region. During these years several important financial institutions were intervened and nonperforming loans rose significantly.

Mexico 
Figure IV.4 presents the case of Mexico. The first shaded region covers an extended period. According to LGS, KR and CK Mexico experienced financial problems almost continuously over 18 years, even though the consensus periods are much shorter: 1982 and 1994-1996.

The first shaded region begins in the early 1980s. CK and LGS point to the government intervention of the financial system as the key event indicating financial problems. In this case, by January 1982 the FSI shows the start of a contraction that lasted several years.

The second shaded area begins in October 1992, date established by KR as the beginning of a new period of crisis. This date precedes by more than one year to the corresponding date of CK and LGS. In this case, the FSI also displays a clear contraction within this period.

Figure IV.1. The Evolution of the FSIs and the Chronologies of CK, LGS and KR in Argentina

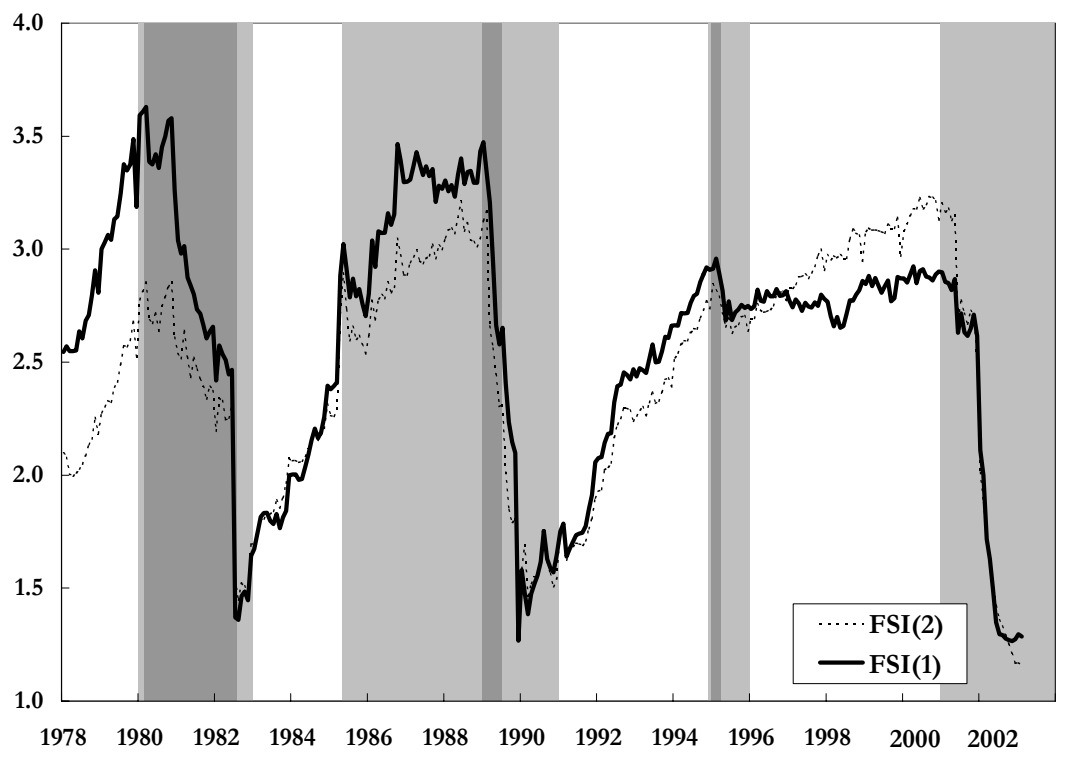

Sources: Author's calculation.

The heavy line presents the benchmark FSI while dashed-line presents the alternative proposed specification. Shaded regions indicate those periods where at least one study identifies banking problems. Dark-shaded regions indicate those periods where identification from the three studies overlaps. Coverage for LGS ranges from 1980 to 1996, from 1970 to early 1998 in the case of KR and from late 1970 s to 2003 in CK.

Figure IV.2. The Evolution of the FSIs and the Chronologies of CK, LGS and KR in Brazil 


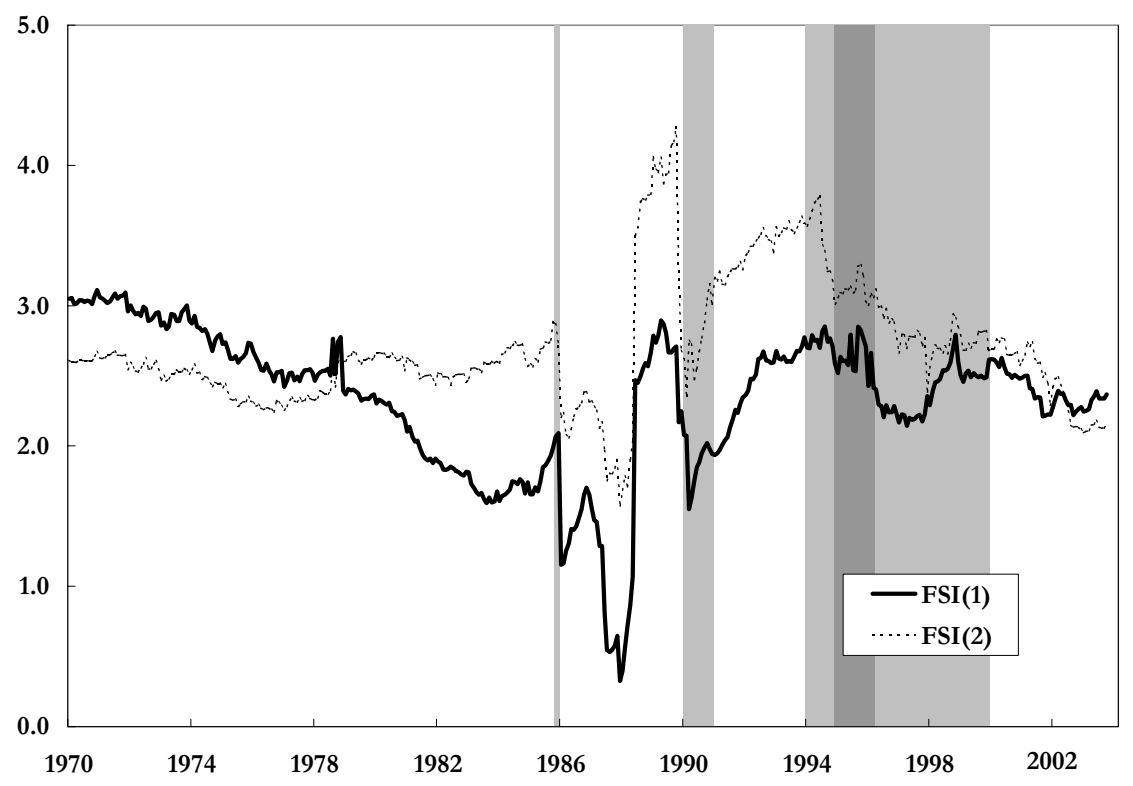

Sources: Author's calculation.

The heavy line presents the benchmark FSI while dashed-line presents the alternative proposed specification. Shaded regions indicate those periods where at least one study identifies banking problems. Dark-shaded regions indicate those periods where identification from the three studies overlaps. Coverage for LGS ranges from 1980 to 1996, from 1970 to early 1998 in the case of KR and from late 1970s to 2003 in CK.

Figure IV.3. The Evolution of the FSIs and the Chronologies of CK, LGS and KR in Chile

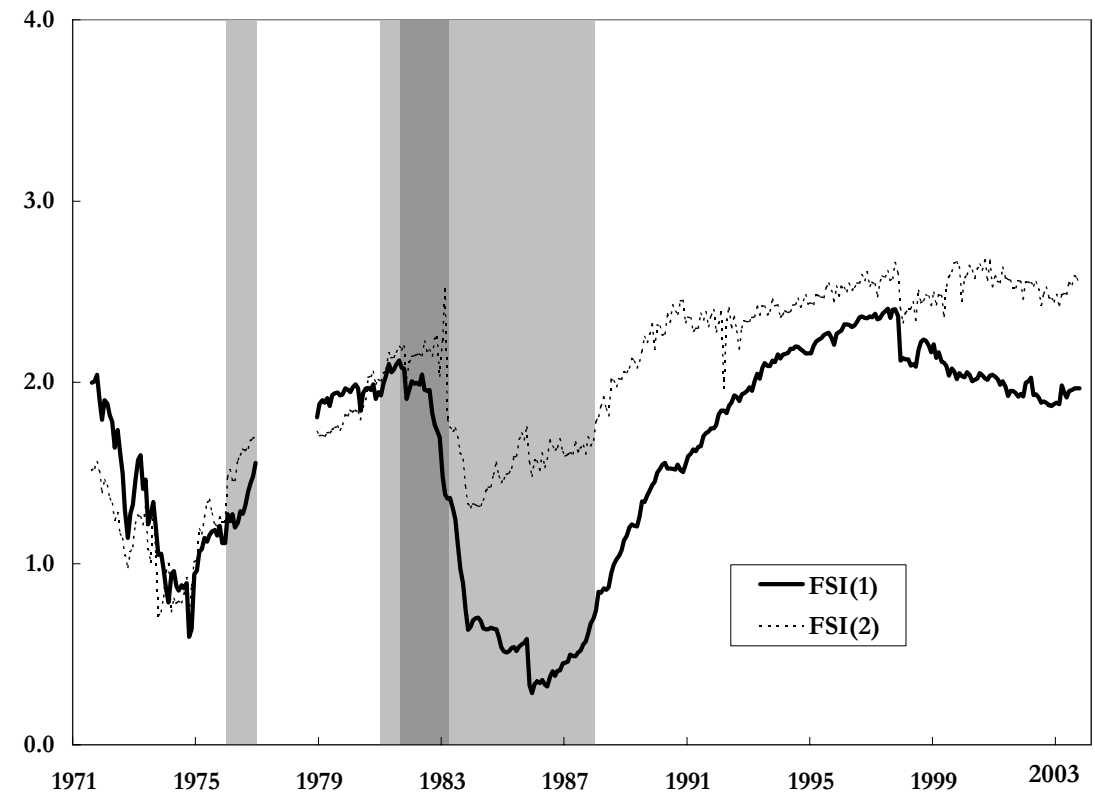

Sources: Author's calculation.

The heavy line presents the benchmark FSI while dashed-line presents the alternative proposed specification. Shaded regions indicate those periods where at least one study identifies banking problems. Dark-shaded regions indicate those periods where identification from the three studies overlaps. Coverage for LGS ranges from 1980 to 1996, from 1970 to early 1998 in the case of KR and from late 1970 s to 2003 in CK.

Figure IV.4. The Evolution of the FSIs and the Chronologies of CK, LGS and KR in Mexico 


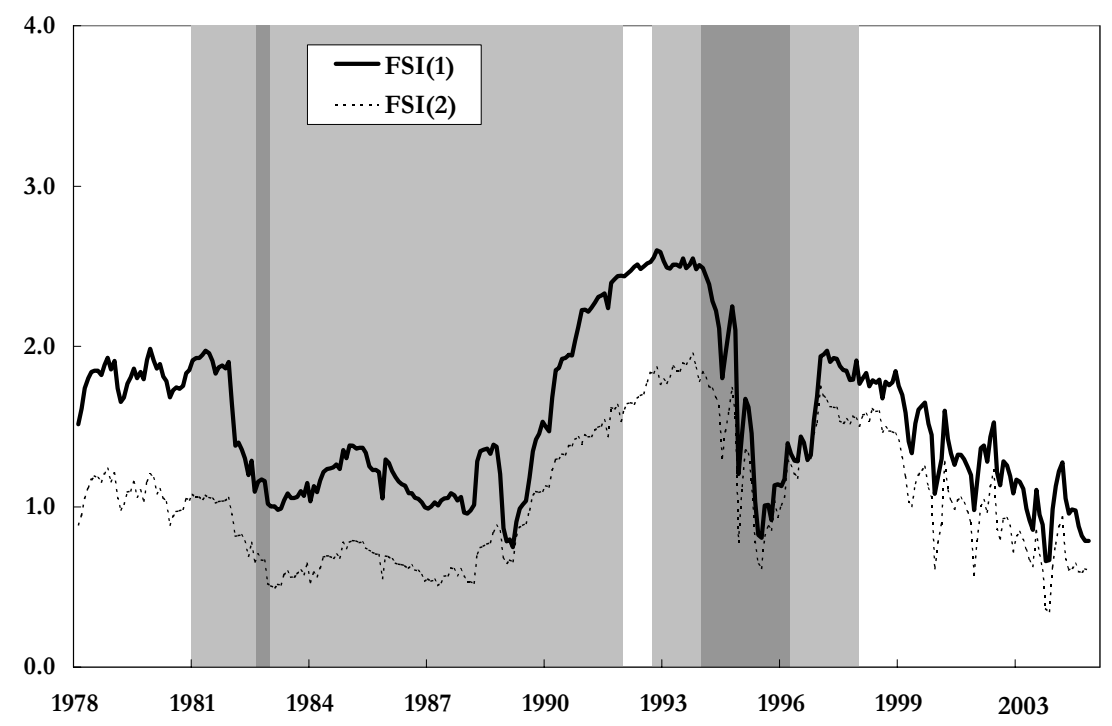

Sources: Author's calculation.

The heavy line presents the benchmark FSI while dashed-line presents the alternative proposed specification. Shaded regions indicate those periods where at least one study identifies banking problems. Dark-shaded regions indicate those periods where identification from the three studies overlaps. Coverage for LGS ranges from 1980 to 1996, from 1970 to early 1998 in the case of KR and from late 1970s to 2003 in CK.

Inspection of Figures I.V.1- I.V.4 reveals that the FSI effectively displays the expected behavior surrounding usually accepted dates. As stated at the beginning of this application, these patterns are not particular cases, but largely apply to other cases considered in this work (see Annex I).

Figures I.V.1- I.V.4 also suggests the need to explore those regions where the FSI suggests increased pressure on the banking system, but no problems were identified by previous studies.

In this regard, an interesting starting point is given by the Mexican case. Until 1997, the FSI behaves very much in line with dates of previous studies, providing reasonable guidance on the presence of the 1980s crisis and the more recent Tequila crisis. On the other hand, a declining pattern since 1997 seems to suggest a possible weakened situation. This behavior may turn out quite consistent with the following considerations. First, there exists extended consensus that Mexico indeed was negatively affected from a financial perspective although at different levels- by international crises emerging after the Tequila, namely Asia (1997), Russia (1998), Brazil (1999) and Argentina (2001). Second, in spite of the time passed since the eruption of the Tequila, bank credit to the private sector has remained largely stagnated. Moreover, a significant fraction of banks' incomes and profits derive from operations with the government. Third, an additional negative influence can be traced-down when Mexico's largest commercial partner -the United States- entered a recession in 2000. All these factors -including increased political uncertainties- affected negatively the banking system, and led it to display overall negative returns during 2001 and urged efforts to recapitalize several entities starting 2002-03.

Another case where the FSI identify a period of increased stress not reported by previous studies is present in Venezuela. The last year of banking problems reported by CK -the only study among those considered here that covers recent years- is 1995 . Additional to this episode, the FSI suggests the presence of a highly stressful situation between late-2001 
and 2003. It is quite interesting to note -besides the contraction of lending and deposits and increased liquidity support provided by the central bank during this period- that Venezuela experience a large GDP contraction of 17\% during this period as well as major political uncertainty. Thus, it seems reasonable to classify of this period as of high stress.

Thus, these last two cases constitute examples of how the FSI may help to identify period of increased stress, particularly where extreme government interventions -such as takeovers, liquidations or forced mergers- were absent.

\section{Application 2: The FSI and Exchange Rate Problems}

Recent years has seen an increased interest in the study of twin crises. As a result, these studies have provided more evidence on the interrelationships among banking and balanceof-payments crises. Therefore, it is of interest to investigate the possible relationships of the FSI with currency problems.

Having this in mind, the figures I.V.5 and I.V.6 are presented. The former presents for the cases of Brazil, Chile, Mexico and Uruguay the evolution of the FSI and (a measure of) the real exchange rate (RER). ${ }^{36}$ The latter presents the evolution of the FSI and an alternative measure of currency market turbulence in Argentina. ${ }^{37}$

Figure I.V.5 shows a rather clear association between the evolution of the FSI and the RER, particularly in the cases of Chile, Mexico and Uruguay. The association is in line with the usual arguments of the twin crises literature and offers additional support to the FSI as an alternative measure to identify banking problems.

According to the index of currency market turbulence presented in the equation III.1, a more proper measure of balance-of-payment problems should include information on foreign reserves. Thus, in order to provide a more adequate measure of this problem the following alternative Index of Exchange Rate Pressure is computed:

$$
I E R P=\frac{R E R}{\sigma_{R E R}}+\frac{r e l_{-} r e s}{\sigma_{r e l \_} r e s} \quad \text { (IV.1), }
$$

where, as before, the RER is defined as $P / e \cdot P^{*}$, with $P$ standing for the consumer price index, $P^{*}$ representing the US consumer price index and $e$ is the nominal exchange rate. In the second term, the variable rel_res is defined as the share of reserves constituted by foreign exchange.

Figure I.V.6 presents the evolution of this alternative measure of currency turbulence and the FSI for the case of Argentina. This figure reveals a close relationship between the FSI and the IERP. If these indexes are considered adequate measures, then this figure supports the view of a strong relationship between banking and balance-of-payments problems in Argentina.

\section{Figure IV.5 The FSI and the Real Exchange Rate Brazil, Chile, Mexico and Uruguay}

\footnotetext{
${ }^{36}$ Real exchange rate is defined as $R E R \equiv P / e \cdot P^{*}$, where $\mathrm{P}$ is the domestic country consumer price index; $\mathrm{P}^{*}$ is the U.S. consumer price index an $\mathrm{e}$ is the nominal exchange rate against the American dollar.

37 These cases are examples of countries with experiences of twin crises.
} 

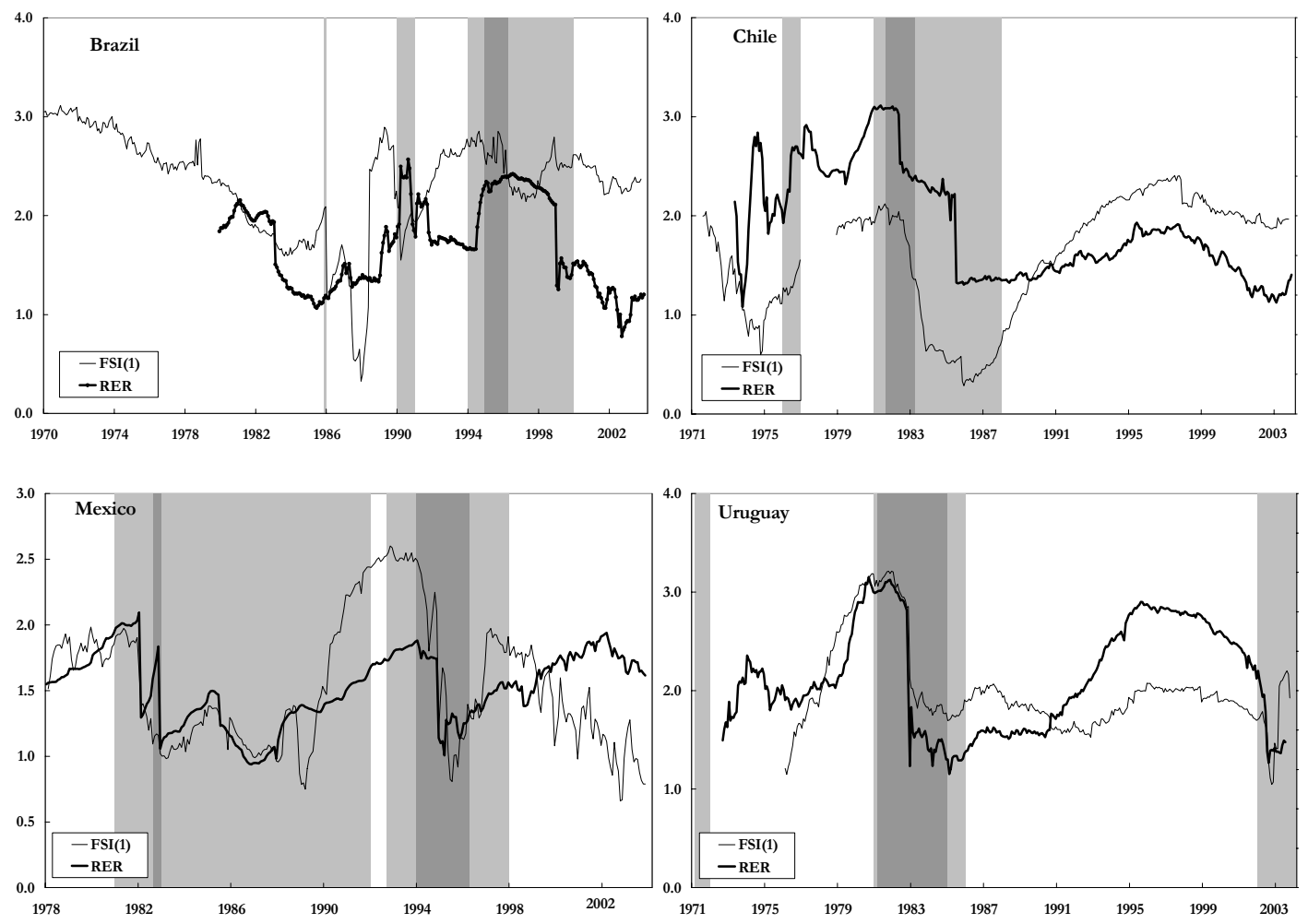

Source: Author's calculations.

Each figure depicts the evolution of the FSI as defined in equation III.2 and a measure of real exchange rate.

Figure IV.5 The FSI and the IERP Argentina

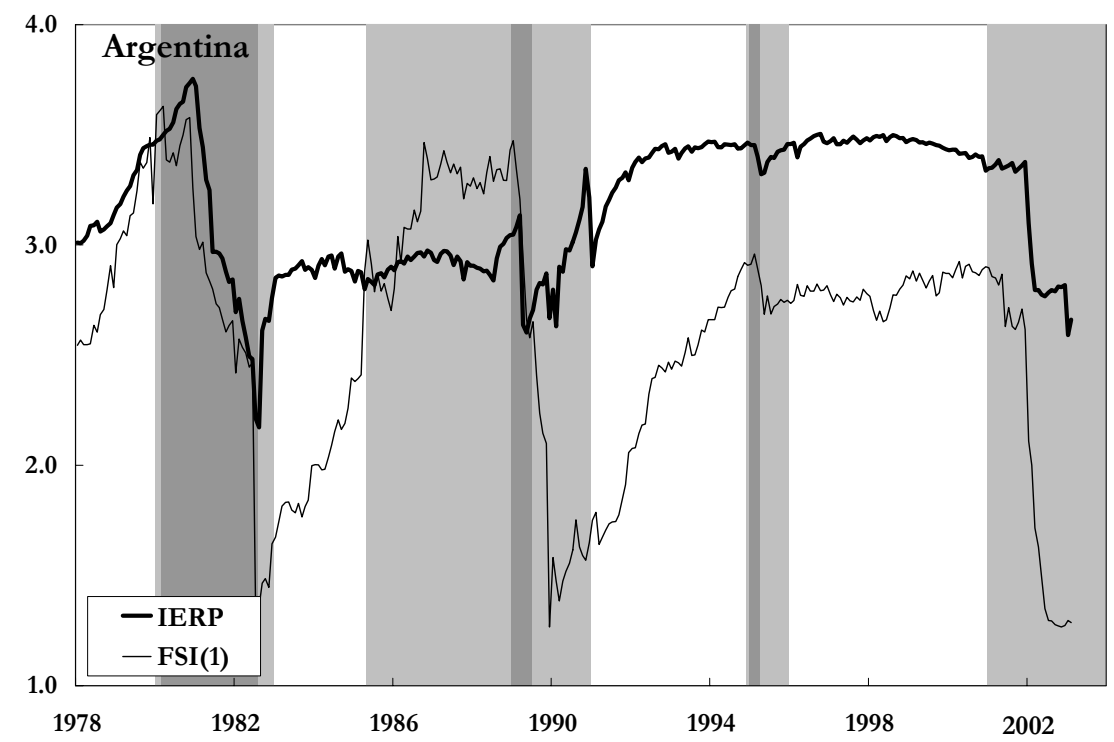

Source: Author's calculations.

The figure depicts the evolution of the FSI as defined in equation III.2 and the index of exchange rate pressure defined in I.V.1 
This clear association between the FSI and these measures of real exchange rate and exchange rate pressure is deemed as an important, additional support to the validity of the FSI as a tool to identify banking problems.

\section{Application 3: A chronology of banking problems}

One of the main purposes of the FSI is to serve as a tool to identify the presence of financial crises. The previous examples (applications 1 and 2) show how the FSI can be used as an alternative (and complementary) procedure to date banking problems.

Annex I presents a survey of episodes of banking stress that were identified using the proposed FSI. ${ }^{38}$ In general, the episodes identified by this index can be associated to episodes of banking problems identified in previous studies -not only with reference to its presence but with reference to duration as well. However, there were cases where the FSI signaled the presence of episodes not identified in other studies. When these situations arose, considerable effort was devoted to understand the origins of discrepancies before accepting it. Conversely, there were few situations where the FSI did not suggest the presence of problems, opposing to previous studies. Also in these cases, particular attention was given to identifying the causes of these divergences and, if necessary, these episodes were included even though they were not detected by FSI. ${ }^{39}$

Additionally, dates are usually accompanied by a short comment on relevant events that surrounded the identified period. ${ }^{40}$ This survey is also complemented with a case-by-case list of short remarks on discrepancies between alternative studies and the present classification.

As other studies also do, the present chronology distinguishes between episodes of first and second magnitude. The criteria used to make this distinction, as well as other operative aspects, are detailed in Annex I.

\footnotetext{
${ }^{38}$ The countries considered were: Argentina, Bolivia, Brazil, Chile, Canada, Colombia, Costa Rica, Ecuador, Mexico, Paraguay, Peru, Venezuela, United States, Austria, Denmark, Finland, Germany, Greece, Iceland, Ireland, Italy, Norway, Portugal, Spain, Sweden, Switzerland, Turkey, United Kingdom, Hong Kong, Indonesia, Israel, Japan, Korea, Malaysia, Philippines, Singapore, Cameroon, Ghana, Kenya, Nigeria, Senegal and South Africa.

39 These cases are adequately identified.

40 These comments rely heavily - even though not exclusively- on the information provided by other studies.
} 


\section{Conclusions}

Over the last few years, many studies investigated on the causes and consequences of banking crises -and its interactions with other economic phenomena, as well. As a rule, these studies usually rely on other previous studies to identify when and where these crises occurred. This procedure is largely justified by the inherent complexity of banking crises.

However, exploration of these commonly cited sources of banking crises dates reveals lack of consensus and the presence of large discrepancies over the timing and duration of these episodes. An example of such discrepancies and their potential consequences was presented in Section II. That section showed how alternative reasonable usage of these widely cited sources may lead to significant changes in the number of counted crisis episodes. ${ }^{41}$

Largely motivated by these discrepancies, this work attempted to explore the identification of banking problems using an alternative procedure based on continuous measure, namely a Financial Stress Index (FSI), based on a few, extensively reported series allowing its application to a large set of countries over extended periods. Application of this FSI to a relatively large sample derived in a chronology of banking problems that compares favorably to previous studies and provides information on the presence of unidentified episodes. Additionally, as an unexpected result, this work finds a strong association between this proposed FSI and continuous measures of balance-of-payments problems. This last result is considered an important, additional support to the validity of the FSI as a tool to identify banking problems.

${ }^{41}$ As stated on several occasions throughout this work, these discrepancies by no means diminish the merits of these previous studies. Moreover, the works of Lindgren, Garcia and Saal (1996), Caprio and Klingebiel (2003) and Kaminsky and Reinhart (1999) are extensively used in this and other works because they are, outstanding research studies. 


\section{Annex I}

\section{Identification of Banking Problems}

The following list presents information on episodes of high and intermediate financial stress. This classification was determined using the FSI of section III. A detailed explanation on this index, concept definition, classification criteria, data sources and other relevant information is provided at the end of this annex. In this list, episodes of high stress are named crises and those classified as of intermediate stress are called significant problems. $^{42} 43$

Dates presented in this list correspond to the application of the following index:

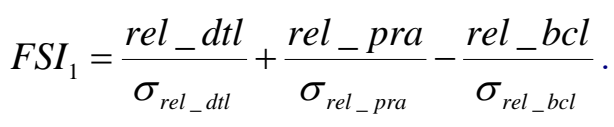

In a few cases, due to missing data, aggregation problems or other reasons a variant of this index (that excludes the last term was used) or the alternative FSI given by:

$$
F S I_{2}=\frac{m m 2}{\sigma_{m m 2}}+\frac{r e l_{\text {_cred }}}{\sigma_{\text {rel_cred }}}-\frac{\text { rel_bcl }}{\sigma_{\text {rel_bcl }}} \text {. }
$$

In each country, a FSI and its twelve-month rate of change are computed. Then, the median contraction and the standard deviation of the contractions are estimated. Next, those periods where the FSI displays a contraction greater than the median plus 1.5 standard deviations are identified and a episode of high stress is assumed to have started since the previous local maximum (in levels) of the FSI. To date the conclusion of this episode, first a long run tendency in computed using the HP filter $(\lambda=100000)$ and the end is marked where the FSI recovers its tendency. The periods identified in this way are initially classified as of high stress. Next, this procedure is repeated excluding from the computation of the median contraction and standard deviation those observations falling in the previous episodes. To give "consistency" to this dates, the calculations were performed using slightly smoothed versions of the FSI $(\lambda=12)$

Data to compute the FSI were taken from the International Financial Statistics (IFS), International Monetary Fund and each concept is defined as follows:

Share of private deposits (rel_dt): the ratio of IFS lines $24+25^{*}$ to lines $24+25^{*}+26^{*}$.

Share of private loans (rel_pra): the ratio of IFS line 22 to lines $20 *+21 *$

Share of credit from monetary authorities (rel_bcl): the ratio of IFS line 26G to lines $24+25^{*}+26^{*}$

M2 multiplier: the ratio of IFS lines 34+35 to line 14 .

Share of private credit in domestic credit: the ratio of IFS line 32D to line 32.

42 As additional information, this annex also includes a a case-by-case list of short remarks on discrepancies between alternatives studies and the present classification.

${ }^{43}$ Dates marked with the symbols $t$, \#, and * correspond to dates extracted from Caprio and Klingebiel (2003), Lindgren, Garcia and Saal (1996) and Kaminsky and Reinhart (1999). 
Annex 
Argentina

Crises

Mar-80 Feb-85

Dec-88 Apr-92

Jan-95 Mar-96

Jan-01 ongoing

Crises

Dec-72 Nov-74

Aug-86

Apr-88 Jun-91

Aug-94 Jun-98

Jun-00 ongoing

Crises

Oct-85 May-88

Jun-89 Jan-92

Nov-95 May-98

Significant problems

Jan-80 Feb-84

Crises

Aug-71 Dec-76

Aug-81 Feb-88

Minor problems

Jul-97 Aug-98

Crises

Aug-82 Apr-86
Initially, more than 70 institutions, comprising $16 \%$ of commercial bank assets and 35 percent of finance company assets, were liquidated or subjected to central bank intervention. Overall, 168 institutions -including banks and other financial institution

Between 1989 and 1990, nonperforming assets reached 27\% of the aggregate portfolio and $37 \%$ of the portfolios of state banks. Failed banks held 40 percent of financial system assets. Institutions affected were primarily state-owned banks.

Eight banks suspended and three banks collapsed. Through September 1995, 45 institutions of 205 were closed or merged. Through the end of 1997 , another 18 banking institutions were closed or merged.

In March 2001, a bank run started In late November 2001, partial withdrawal restrictions (corralito) were imposed to transactional accounts while fixedterm deposits (CDs) were reprogrammed (corralon). In January 2002, bank assets were asymmetrically pesi

At the end of 1972 , deposits fell by $22 \%$ and deposit money banks' claims on the private sector by $16 \%$ in two months. After a year of relative calm, deposits started to fall again, and from mid 1973 to early 1974 deposits suffer a cumulated loss of $35 \%$ and

Between 1986-1988, five banks were liquidated. Banking system nonperforming loans reached 30 percent in 1987; in mid-1988 reported arrears stood at 92 percent of commercial banks' net worth. Between 1988 and 1991, credit from the monetary authority consti

Two banks with 11 percent of banking system assets were closed in 1994. In 1995, 4 of 15 domestic banks, accounting for 30 percent of banking system assets, experienced liquidity problems and suffered high nonperforming loans. Institutions affected were $p$

By the end of 1999 deposits started to decrease, falling $10 \%$ in up to October 2000. After a few months of recovery, deposits started to fall again in March 2001. In 2002, deposits contracted sharply from June to July more than $13 \%$ making aggregate deposit

Liquidity support to banks. Stock prices fell significantly.

Private deposits and banks' claims on the private sector declined. In 1990, deposits were converted to bonds.

Until 1996, twenty-nine banks, holding $15.4 \%$ of total deposits, were subjected to official intervention, placed under special administration, or received assistance to merge. During 1995 and 1996 banks' claims on private sector declined significantly. By

With the eruption of the LDCs' crisis Brazilian banks faced liquidity problems.

At the end of 1971, deposits stated to refrain its pace firt and to contract later; by late 1972 deposits were around $30 \%$ lower than a year before (and continued falling over the next months); central bank assistance rose to almost one fourth of total dep

In 1981 the authorities intervened in four banks and four nonbank financial institutions accounting for 33 percent of outstanding loans. In 1983 the authorities intervened in seven banks and one financiera accounting for 45 percent of financial system ass

As a consequence of the Asian crisis, Chile faced some liquidity shortages.

The Central Bank intervened in six major banks accounting for 25 percent of banking system assets and 8 finance companies. 15\% of loans were nonperforming in $1984-1985$ (5.5.\% in $1980,6.6 \%$ in 1988). Some insolvent banks were nationalized in 1985-1986.

Dec-87 -.- 
Significant problems

Mar-98 Jul-02

\section{Costa Rica}

Crises

Jan-70 Nov-71

Jan-74 Dec-75

Feb-79 Nov-81

Secondar Level 2

Apr-94 Mar-98

Ecuador

Crises

Jul-82 Oct-85

Nov-94 Jun-01

Significant problems

Aug-76 Aug-79

Mexico

\section{Crises}

Sep-81 Apr-90

Dec-92 Dec-96

Significant problems

Jul-01 Oct-02

Crises

Dec-82 Nov-90

Jan-95 Dec-98

Feb-01 Ongoing

Crises

May-73 Feb-80

Feb-83 Jan-91

\section{Uruguay Crisis}

Mar-71 Dec-71

Dec-81 Feb-86

Sep-99 Apr-03
Bank credit on the private sector started to refrain its pace on early 1998 and later turn into outright decline. The financial system as a whole started to show negative returns by the end of 1998 until the end of 2001 . Nonperforming loans rose from 5.5

Liquidity support to banks.

Liquidity support to banks responding to contracting private demand deposits.

The central bank provided extensive liquidity support.

One large state-owned commercial bank was closed in December 1994 The ratio of overdue loans (net of provisions) to net worth in state commercial banks exceeded 100\% in June 1995

Central bank liquidity support started to increase its presence in banks balance sheets since late 1970s; this process accelerated in 1982 and again in 1984. A program exchanging domestic for foreign debt was implemented to bail out banking system.

By the end of 1995, several small financial institutions were intervened and 30 financial institutions and 7 banks were receiving extensive liquidity support. In March 1996, the fifth largest commercial bank was intervened. NPLs more than trebled from 8.1

The central bank started to increase its liquidity support to banks.

Government took over troubled banking system. Private deposits and credit on the private sector started a clear contraction in 1982. A sustained recovery in private deposits and credit on the private sector began in late 1980s.

In 1994, 9 out of 34 commercial banks -accounting for 19\% of financial system assets- were deemed insolvent and intervened. 11 participated in the loan/purchase recapitalization program. Additional reforms were introduced, and after five years, in 1998, 1

Overall, the financial system display negative returns in 2001

Aggregate deposits declined, almost continuously, from 1982 to 1986, and recover previous levels at late 1980s. Similar behavior was displayed by credit on private sector. Liquidity support by the central bank increased steadily over the 1980 s.

4 banks and six finance institutions accounting for 10 percent of financial system deposits were intervened. By 1998 the government had intervened in six other financial institutions, including the country's largest public bank and the largest savings and

One bank was closed in 2001 and another one became insolvent in 2002. Banks in the system continue to experience rising NPLs: $8.1 \%$ in 1998,12\% in 2000 , around $15.0 \%$ in $2002 / 3$ and a slight decline in the first quarter of 2004.

Bank credit on the private sector declined steadily from 1974 to 1979 and recover the initial level at the end of 1981. Deposits' decline began in 1975 and recover its previous level in 1983. Liquidity support increased significantly from 1975 to 1978 and

Two large banks failed. The rest of the system suffered from high nonperforming loans and financial disintermediation following the nationalization of the banking system in 1987.

Affected institutions accounted for 30 percent of financial system assets; insolvent banks accounted for 20 percent of financial system deposits. Eleven percent of loans were nonperforming in 1982, 59\% in 1986 .

The Government-owned mortgage bank was recapitalized in December 2001. The banking system experienced a large outflow of deposits (33\% during the first seven months of 2002). In 2002, four banks were closed (representing $33 \%$ of total bank assets). Fixed-t 
Significant problems 


\begin{tabular}{|c|c|c|c|}
\hline & Aug-87 & Feb-94 & $\begin{array}{l}\text { Private deposits and bank credit on the private sector declined on early } \\
\text { 1990s. }\end{array}$ \\
\hline \multirow[t]{4}{*}{ Venezuela } & $\begin{array}{l}\text { Crises } \\
\text { Jul-86 }\end{array}$ & Nov-89 & $\begin{array}{l}\text { Several bank failures: Banco de Comercio (1985), BHCU (1985), BHCO } \\
\text { (1985), and Banco Lara (1986) and large contractions of private deposits } \\
\text { and banks' claims on the private sector. Central bank liquidity support rose } \\
\text { significantly during late 1980s. }\end{array}$ \\
\hline & Apr-93 & Jan-95 & $\begin{array}{l}\text { Insolvent banks accounted for } 35 \text { percent of financial system deposits. In } \\
1994 \text { the authorities intervened in } 17 \text { of } 47 \text { banks that held } 50 \text { percent of } \\
\text { deposits and nationalized } 9 \text { banks and closed } 7 \text { others. The government } \\
\text { intervened in } 5 \text { additional banks in } 1\end{array}$ \\
\hline & Oct-01 & Apr-03 & $\begin{array}{l}\text { In } 2002 \text { banks' claims on private sector started to decline. Responding to } \\
\text { declining deposits, liquidity support increased significantly. Between 2003- } \\
2001 \text { GDP contracted more than } 17 \% \text {. }\end{array}$ \\
\hline & $\begin{array}{l}\text { Significa } \\
\text { Jan-76 } \\
\text { Apr-82 } \\
\text { Feb-95 }\end{array}$ & $\begin{array}{l}\text { te problems } \\
\text { Jun-80 } \\
\text { May-83 } \\
\text { Sep-97 }\end{array}$ & $\begin{array}{l}\text { Banco Nacional de Descuento failed in } 1978 \text { and BANDAGRO in } 1981 \\
\text { Banco de los Trabajadores de Venezuela failed in } 1982\end{array}$ \\
\hline Canada & \multicolumn{2}{|c|}{ Significant problems } & †\# Fifteen members of the Canadian Deposit Insurance Corporation, including \\
\hline United States & $\begin{array}{l}\text { Significa } \\
1980\end{array}$ & $\begin{array}{l}\text { tt problems } \\
1992\end{array}$ & $\begin{array}{l}\text { † More than } 1,400 \text { savings and loan institutions and } 1,395 \text { banks failed. } 4.1 \% \\
\text { of commercial bank loans were nonperforming in } 1987\end{array}$ \\
\hline \multirow[t]{4}{*}{ Hong Kong } & $\begin{array}{l}\text { Crisis } \\
\text { Aug-94 }\end{array}$ & Sep-96 & \\
\hline & \multicolumn{2}{|c|}{ Significant problems } & \\
\hline & 1982 & 1983 & $\dagger$ Nine deposit-taking companies failed. \\
\hline & $\begin{array}{l}1983 \\
1998\end{array}$ & 1986 & $\begin{array}{l}\text { † Seven banks or deposit-taking institutions were liquidated or taken over. } \\
\text { † One large investment bank failed. }\end{array}$ \\
\hline \multirow[t]{4}{*}{ Indonesia } & $\begin{array}{l}\text { Crisis } \\
\text { Mar-97 }\end{array}$ & Mar-01 & $\begin{array}{l}\text { Banks suffered a sharp deposit withdrawal and the authorities responded } \\
\text { providing extensive liquidity support. Through May 2002, Bank Indonesia } \\
\text { had closed } 70 \text { banks and nationalized 13, of a total of } 237 \text {. Nonperforming } \\
\text { loans were estimated at } 48.5 \% \text { in } 1998\end{array}$ \\
\hline & \multicolumn{2}{|c|}{ Significant problems } & \\
\hline & Nov-80 & Dec-85 & $\begin{array}{l}\text { The ratio of liquidity support to bank's liabilities (or deposits) increased } \\
\text { significantly during the first part of } 1980 \text { s. }\end{array}$ \\
\hline & Aug-92 & Sep-94 & $\begin{array}{l}\text { A large private bank was closed in } 1992 . \text { Total NPLs were over } 25 \% \text { of total } \\
\text { lending in } 1993 \text {-of which more than } 70 \% \text { were concentrated in state-owned } \\
\text { banks- and declined to } 12 \% \text { in September } 1995 .\end{array}$ \\
\hline \multirow{4}{*}{ Israel } & Crisis & & \\
\hline & May-77 & Aug-81 & $\begin{array}{l}\text { Almost the entire banking sector was affected, representing } 60 \text { percent of } \\
\text { stock market capitalization. The stock exchange closed for } 18 \text { days, and } \\
\text { bank share prices fell more than } 40 \text { percent. }\end{array}$ \\
\hline & \multicolumn{2}{|c|}{ Significant problems } & \\
\hline & Jan-74 & Dec-75 & The central bank provided liquidity support to banks. \\
\hline Japan & $\begin{array}{l}\text { Significa } \\
1991\end{array}$ & $\begin{array}{l}\text { nt problems } \\
\text { present }\end{array}$ & $\begin{array}{l}\text { †anks suffered from sharp decline in stock market and real estate prices. In } \\
1995 \text { the official estimate of nonperforming loans was } 40 \text { trillion yen ( } \$ 469 \\
\text { billion, or } 10 \text { percent of GDP). An unofficial estimate put nonperforming } \\
\text { loans at } \$ 1 \text { trillion, equival }\end{array}$ \\
\hline \multirow[t]{2}{*}{ Korea } & Crises & & \\
\hline & $\begin{array}{l}\text { Mar-72 } \\
\text { Jul-97 }\end{array}$ & $\begin{array}{l}\text { Dec-76 } \\
\text { Mar-99 }\end{array}$ & $\begin{array}{l}\text { Private deposits contracted. The central bank provided liquidity support. } \\
\text { Banks' demand deposits started to fell in } 1997 \text {. At the end of } 1997 \text { central } \\
\text { bank's liquidity support increased significantly. Through May } 2002,5 \text { banks } \\
\text { were forced to exit the market through a "purchase and assumption formula" } \\
\text { and } 303 \text { financial institution }\end{array}$ \\
\hline
\end{tabular}


Secondary problems

May-83 Mar-89

Malaysia

\section{Crises}

19851988

Jun-96 Dec-99

Significant problems

Jun-92 Mar-95

Philippines

Crises

Jan-72 Jan-77

Jul-83 Sep-87

Feb-96 Aug-02

Significant problems

Aug-90 Sep-92

Singapore Crises

Oct-70 Jun-74

Significant problems

Jun-83 May-90

Turkey

\section{Crises}

Jul-77 May-81

Dec-85 Jun-89

Feb-97 Nov-01

Significant problems

Jul-72 Jun-75

Jun-92 Dec-94

Finland

Crisis

Mar-73 Mar-78

Feb-89 Dec-93

Significant problems

Jul-79 Sep-81

Feb-86 Mar-87

Germany

Significant problems
Nonperforming loans of deposit money banks rose significantly in the first half of the $1980 \mathrm{~s}$, exceeding $7 \%$ of total assets in 1986 . The ratio of nonperforming loans to total assets declined subsequently to $0.9 \%$ in 1995

\# The largest domestic bank wrote off nonperforming loans equivalent to approximately $1.4 \%$ of GDP in 1983 . Insolvent institutions accounted for 3 percent of financial system deposits; marginally capitalized and possibly insolvent institutions accounted for

Finance company sector was restructured and reduced from 39 to 10 through mergers. Two finance companies were taken over by the Central Bank, including the largest independent finance company. Two banks deemed insolvent. Nonperforming loans peaked between

Liquidity support to banks

Problems in two public banks accounting for 50 percent of banking system assets, six private banks accounting for 12 percent of banking system assets, 32 thrifts accounting for 53 percent of thrift banking assets, and 128 rural banks.

Banks accounting por $1.6 \%$ of banking system assets failed in 1981 . Thoug the mid1980s, a number of institutions failed or were taken over by govrernment financial institutions. Nonperforming assets of two state-owned institutions were transferred to a go

Banks' claims on the private sector declined.

Private demand deposits contracted around $30 \%$. The central bank provided liquidity support.

Commercial banks' nonperforming loans rose to about $\$ 200$ million, or 0.6 percent of GDP.

Private deposits and lending to private sector declined from 1997 to 1980. In response, the central bank provided liquidity support.

Lending to private sector declined in 1984 and 1989. Between 1986 and 1988 the central bank increased its liquidity support to banks.

With the eruption of the Asian crisis, the central bank started to increase its liquidity support to banks as private deposits -mainly demand deposits- fell. In 1998 banks' claims on private sector started to decline while NPLs almost trebled to $6.7 \%$ from

Banks received liquidity support.

The start of the Persian Gulf war led to bank runs. Depositor runs in the spring of 1994 resulted in the closure of 3 medium-sized banks. To stem further runs, the government introduced full deposit insurance in May 1994.

Private deposits contracted in 1973 and 1974. Central bank provided liquidity support during the period.

In 1991 banks experienced a liquidity crisis. Nonperforming loans and credit losses reached $13 \%$ of total exposure at their peak in 1992. Savings banks were badly affected; government took control of three banks that together accounted for 31 percent of sy

Liquidity support to banks Liquidity support to banks

Aug-75 Mar-78

So-called Giroinstitutions faced problems.

There were major problems at state-owned banks in East Germany following unification. The costs were handled by an extrabudgetary fund. 


\begin{tabular}{|c|c|c|c|}
\hline \multirow[t]{2}{*}{ Greece } & \multicolumn{3}{|l|}{ Crisis } \\
\hline & Aug-91 & Aug-94 & $\begin{array}{l}\text { There were problems that required significant injections of public funds into } \\
\text { specialized lending institutions }\end{array}$ \\
\hline \multirow[t]{4}{*}{ Iceland } & \multicolumn{3}{|c|}{ Significant problems } \\
\hline & Sep-73 & Nov-78 & \\
\hline & Apr-81 & May-85 & $\begin{array}{l}\text { One of three state-owned banks became insolvent and was eventually } \\
\text { privatized in a merger with three private banks. }\end{array}$ \\
\hline & Sep-92 & Dec-93 & $\begin{array}{l}\text { The government was forced to inject capital into one of the largest state- } \\
\text { owned commercial bank after it suffered serious loan losses. }\end{array}$ \\
\hline \multirow[t]{4}{*}{ Ireland } & \multicolumn{3}{|c|}{ Significant problems } \\
\hline & \multicolumn{2}{|c|}{1985} & $\begin{array}{l}\text { \# One of the four clearing banks wrote off one fourth of its capital when its } \\
\text { insurance subsidiary sustained losses and was placed under administration. }\end{array}$ \\
\hline & Feb-89 & Jun-90 & Liquidity support to banks \\
\hline & Apr-92 & Mar-93 & Liquidity support to banks \\
\hline \multirow[t]{4}{*}{ Italy } & \multicolumn{3}{|l|}{ Crisis } \\
\hline & Dec-89 & Jun-95 & $\begin{array}{l}\text { Problems were concentrated in the south, affecting particular institutions. } \\
\text { Systemwide, nonperforming loans were } 10 \% \text { of total in } 1995 \text {. During } 1990- \\
94,58 \text { banks (accounting for } 11 \% \text { of total lending) were in difficulties and } \\
\text { were merged withe other institut }\end{array}$ \\
\hline & \multicolumn{3}{|c|}{ Significant problems } \\
\hline & Aug-81 & Apr-86 & $\begin{array}{l}\text { Deposits declined from late } 1970 \text { s to early } 1980 \text { s. In } 1983 \text { central bank } \\
\text { started to increase its liquidity support to banks. }\end{array}$ \\
\hline \multirow[t]{5}{*}{ Norway } & Crisis & & \\
\hline & Oct-85 & Nov-92 & $\begin{array}{l}\text { The Central Bank provided special loans to six banks suffering from the } \\
\text { recession of } 1985-86 \text { and from problem real estate loans. The state took } \\
\text { control of the three largest banks (with } 85 \text { percent of banking system assets, } \\
\text { whose loan losses had wiped out c }\end{array}$ \\
\hline & \multicolumn{3}{|c|}{ Significant problems } \\
\hline & Jul-81 & Apr-83 & Deposits stagnated \\
\hline & Jan-98 & Aug-01 & \\
\hline \multirow[t]{2}{*}{ Portugal } & \multicolumn{3}{|c|}{ Significant problems } \\
\hline & Oct-91 & Dec-95 & $\begin{array}{l}\text { Deposits contracted during 1990. In } 1993 \text { lending to private sector slowed } \\
\text { and liquidity support increased significantly during } 1994 \text { and } 1995 .\end{array}$ \\
\hline \multirow[t]{4}{*}{ Spain } & Crisis & & \\
\hline & Jan-76 & Apr-86 & $\begin{array}{l}\text { As early as } 1974 \text { demand deposits started to decline and liquidity support } \\
\text { was increased. In } 1976 \text { stagnation affected all deposits and by } 1977 \text { liquidity } \\
\text { support to banks increased significantly. In 1978-83, } 24 \text { institutions were } \\
\text { rescued, } 4 \text { were liquidated, }\end{array}$ \\
\hline & \multicolumn{3}{|c|}{ Significant problems } \\
\hline & Jun-92 & Jan-96 & $\begin{array}{l}\text { In 1991short-term deposits started to shrink. On early } 1992 \text { the central bank } \\
\text { started to increase its liquidity support to banks. Assistance boosted as } \\
\text { deposits drain accelerated. Banks curtailed its lending to private sector } \\
\text { (lending didn't recovered its }\end{array}$ \\
\hline \multirow[t]{5}{*}{ Sweden } & Crisis & & \\
\hline & Aug-91 & Aug-93 & $\begin{array}{l}\text { Nordbanken and Gota Bank, accounting for } 22 \text { percent of banking system } \\
\text { assets, were insolvent. Sparbanken Foresta, accounting for } 24 \text { percent of } \\
\text { banking system assets, intervened. Overall, five of the six largest banks, } \\
\text { accounting for more than } 70 \text { percent o }\end{array}$ \\
\hline & \multicolumn{3}{|c|}{ Significant problems } \\
\hline & Nov-73 & Jul-75 & Liquidity support to banks following protracted deposit loss. \\
\hline & Dec-84 & Dec-85 & Liquidity support to banks \\
\hline \multirow[t]{4}{*}{ United Kingdom } & \multicolumn{3}{|c|}{ Significant problems } \\
\hline & 1974 & 1976 & † Secondary banking crisis \\
\hline & 1984 & & \# Johnson Matthey failed. \\
\hline & Feb-90 & Jun-96 & $\begin{array}{l}\text { Bank of Credit and Commerce International D351(1991), and Barings } \\
\text { (1995) failed. }\end{array}$ \\
\hline
\end{tabular}




\begin{tabular}{|c|c|c|c|}
\hline \multirow[t]{5}{*}{ Cameroon } & \multicolumn{3}{|l|}{ Crisis } \\
\hline & Jul-86 & Nov-91 & $\begin{array}{l}\text { Deposits started to fall in mid-1985 and in } 1986 \text { the central bank } \\
\text { substantially increased its liquity support to banks. In } 1989 \text { banking system } \\
\text { nonperforming loans reached } 60-70 \text { percent. Five commercial banks were } \\
\text { closed and three banks were restructured. }\end{array}$ \\
\hline & 1995 & 1998 & $\begin{array}{l}\dagger \text { At the end of } 1996 \text { nonperforming loans accounted for } 30 \text { percent of total } \\
\text { loans. Three banks were restructured and two were closed. }\end{array}$ \\
\hline & \multicolumn{3}{|c|}{ Significant problems } \\
\hline & Aug-77 & Jun-84 & Liquidity support to banks. \\
\hline \multirow[t]{6}{*}{ Ghana } & Crises & & \\
\hline & Mar-87 & Jul-90 & $\begin{array}{l}\text { Seven banks deemed insolvent. According to some estimates NPLs peaked } \\
\text { at } 60-70 \% \text { in } 1989 .\end{array}$ \\
\hline & Aug-93 & Nov-96 & $\begin{array}{l}\text { Sustained increase in liquidity support boosted by deposits fall in } 1993 \text { and } \\
\text { 1995. Claims on private sector also contracted. NPLs reached around 30\% } \\
\text { in } 1996\end{array}$ \\
\hline & Oct-98 & Ongoing & $\begin{array}{l}\text { Short-term deposits started to fall during 1999. As a result of the increased } \\
\text { liquidity support by the central bank, deposits recover towards the end of } \\
\text { the year. However, in spite of the large liquidity assistance, short-term } \\
\text { deposits contracted sharply }\end{array}$ \\
\hline & \multicolumn{3}{|c|}{ Significant problems } \\
\hline & Aug-81 & May-84 & Private deposits experienced a prolonged deterioration until 1984. \\
\hline \multirow[t]{6}{*}{ Kenya } & Crises & & \\
\hline & Apr-74 & Jul-75 & $\begin{array}{l}\text { The central bank provided liquidity support as private deposits (mainly short. } \\
\text { term) fell. In } 1977 \text { lending to private sector recovered its 1974's level. }\end{array}$ \\
\hline & Jun-92 & Nov-95 & $\begin{array}{l}\text { Liquidity support from the central bank increased significantly and both } \\
\text { private deposits and lending to private sector contracted. }\end{array}$ \\
\hline & Feb-97 & Nov-02 & $\begin{array}{l}\text { NPLs were } 27 \% \text { in } 1998 \text {, averaged } 33 \% \text { in } 1999-2000,29 \% \text { in } 2001-02 \text { and } \\
\text { decreased to around } 22 \% \text { in } 2003-04 .\end{array}$ \\
\hline & \multicolumn{3}{|c|}{ Significant problems } \\
\hline & Jul-85 & Sep-86 & $\begin{array}{l}\text { Private deposits stagnated since } 1978 \text {, and started to decline -along with } \\
\text { lending to private sector- since } 1981 \text { to } 1984 \text {; initial levels were recovered }\end{array}$ \\
\hline
\end{tabular}
toward 1986.

\begin{tabular}{|c|c|c|c|}
\hline \multirow[t]{6}{*}{ Nigeria } & \multicolumn{3}{|l|}{ Crises } \\
\hline & Jan-72 & Dec-77 & Short-term deposits fell in 1974 and aggregate private deposits in 1977. \\
\hline & Nov-90 & Aug-97 & $\begin{array}{l}\text { In } 1991,77 \% \text { of loans were nonperforming. In } 1993 \text { insolvent banks } \\
\text { accounted for } 20 \text { percent of banking system assets and } 22 \text { percent of } \\
\text { deposits. Of } 115 \text { banks, } 34 \text {, accounting for } 10 \% \text { of deposits, were technically } \\
\text { insolvent at the end of } 1994 \text {. In } 1995 \text { almost }\end{array}$ \\
\hline & Dec-98 & Nov-00 & $\begin{array}{l}\text { NPLs were } 19.6 \% \text { in } 1998 \text { and peaked at } 25.6 \% \text { in } 1999 \text {; then, slightly } \\
\text { decreased to } 22.6 \% \text { in } 2000 \text { and } 16 \% \text { in } 2001 .\end{array}$ \\
\hline & \multicolumn{3}{|c|}{ Significant problems } \\
\hline & Jan-87 & Apr-89 & Deposits and lending decreased. \\
\hline \multirow[t]{5}{*}{ Senegal } & \multicolumn{3}{|l|}{ Crises } \\
\hline & Aug-87 & Aug-93 & $\begin{array}{l}\text { In } 1988,50 \text { percent of banking system loans were nonperforming, reform } \\
\text { was implemented in 1988-1991; } 8 \text { banks were liquidated (six commercial } \\
\text { banks and one development bank, accounting for } 20-30 \text { percent of financial } \\
\text { system assets) and the remaining } 8 \text { were restructured }\end{array}$ \\
\hline & Jul-97 & Apr-00 & Time and saving deposits contracted and liquidity support increased. \\
\hline & \multicolumn{3}{|c|}{ Significant problems } \\
\hline & Jul-78 & Jan-84 & $\begin{array}{l}\text { Short-term deposits declined and aggregate deposits remain stagnated } \\
\text { from } 1979 \text { to } 1986 \text {. Lending to private sector started to decrease in 1982-83. } \\
\text { Liquidity support increased from } 1978 \text { to } 1984 \text {. }\end{array}$ \\
\hline \multirow[t]{3}{*}{ South Africa } & \multicolumn{3}{|c|}{ Significant problems } \\
\hline & Oct-74 & Feb-81 & $\begin{array}{l}\text { Short-term deposits declined from } 1974 \text { to } 1979 \text {. Lending to private sector } \\
\text { contracted from } 1976 \text { to } 1979 \text { (Trust Bank experienced problems in 1977) }\end{array}$ \\
\hline & Apr-85 & Jun-91 & $\begin{array}{l}\text { In } 1985 \text {, banks experienced problems due to large short-term foreign } \\
\text { liabilities; short-term deposits declined. Lending to private sector declined } \\
\text { between } 1986 \text { and 1987. After 1989, some banks are experienced } \\
\text { problems. }\end{array}$ \\
\hline
\end{tabular}




\begin{tabular}{|c|c|c|}
\hline \multirow[t]{14}{*}{ Argentina } & \multirow[t]{3}{*}{ KR } & Beginning: march 1980. Peak: July 1982 \\
\hline & & \multirow{2}{*}{$\begin{array}{l}\text { Beginning: May 1985. Peak: June } 1989 \\
\text { Beginning: December 1994. Peak: March } 1995\end{array}$} \\
\hline & & \\
\hline & \multirow[t]{4}{*}{ CK } & 1980-82 \\
\hline & & $1989-1990$ \\
\hline & & 1995 \\
\hline & & $2001-$ \\
\hline & LGS & \\
\hline & & $1989-1990$ \\
\hline & & January 1995-September 1995 \\
\hline & FSI & Beginning: March 1980. End: February 1985 \\
\hline & & Beginning: December 1988. End: April 1992 \\
\hline & & Beginning: January 1995. . End: March 1996 \\
\hline & & Beginning: January 2001. End: Ongoing \\
\hline \multirow[t]{10}{*}{ Bolivia } & KR & Beginning: October 1987. Peak: June 1988. \\
\hline & CK & $1986-1988$ \\
\hline & & 1994- \\
\hline & LGS & 1986-1987 \\
\hline & & Significant \\
\hline & FSI & Beginning: December 1972. End: November 1974. \\
\hline & & Beginning: February 1982. End: August 1986. \\
\hline & & Beginning: April 1988. End: June 1991. \\
\hline & & Beginning: August 1994.End: june 1998. \\
\hline & & Beginning: June 2000. End: May 2003. \\
\hline \multirow[t]{9}{*}{ Brazil } & KR & Beginning: November 1985. Peak: November 1985 \\
\hline & & \multirow{2}{*}{$\begin{array}{l}\text { Beginning: December } 1994 \text {. Peak: March } 1996 . \\
1990\end{array}$} \\
\hline & CK & \\
\hline & & 1994-1999 \\
\hline & LGS & Significant \\
\hline & FSI & Beginning: January 1980. February 1984. Significant. \\
\hline & & Beginning: October 1985. End: May 1988. \\
\hline & & Beginning: June 1989. End: January 1992. \\
\hline & & Beginning: November 1995. End: March 1998. \\
\hline Chile & KR & Beginning: September 1981. Peak: March 1983. \\
\hline & CK & 1976 \\
\hline & & 1981-1986 \\
\hline & LGS & 1981-1987 \\
\hline & FSI & Beginning: August 1971 December 1976. \\
\hline & & Beginning: August 1981.End: February 1988. \\
\hline & & Beginning: July 1997.End: August 1998. Minor problem \\
\hline
\end{tabular}




\begin{tabular}{|c|c|c|}
\hline \multirow[t]{6}{*}{ Colombia } & KR & Beginning: July 1982. Peak: June 1985. \\
\hline & CK & $1982-1987$ \\
\hline & LGS & $1982-1985$ \\
\hline & FSI & Beginning: August 1982. End: April 1986. \\
\hline & & Beginning: December 1987. End: No data. \\
\hline & & Beginning: June 2001. End: July 2002. Significant \\
\hline \multirow[t]{8}{*}{ Costa Rica } & KR & - \\
\hline & CK & ? (several Instances) \\
\hline & & $1994-$ \\
\hline & LGS & Significant \\
\hline & FSI & Beginning: January 1970 End: November 1971. \\
\hline & & Beginning: January 1974. End: December 1975. \\
\hline & & Beginning: February 1979. End: November 1981. \\
\hline & & Beginning: April 1994. End: March 1998. Significant \\
\hline \multirow[t]{8}{*}{ Ecuador } & KR & - \\
\hline & CK & Early 1980s \\
\hline & & $1996-1997$ \\
\hline & & 1998-present \\
\hline & LGS & Significant \\
\hline & FSI & Beginning: August 1976. End: August 1979. Significant \\
\hline & & Beginning: July 1982. End: October 1985. \\
\hline & & Beginning: November 1994. End: June 2000. \\
\hline \multirow[t]{10}{*}{ Mexico } & KR & Beginning: September 1982. Peak: June 1984. \\
\hline & & Beginning: October 1992. Peak: March 1996. \\
\hline & & Beginning: . Peak: . End: . \\
\hline & CK & $1981-1991$ \\
\hline & & 1994-1997 \\
\hline & LGS & 1982 \\
\hline & & 1994- \\
\hline & FSI & Beginning: September 1981. End: April 1990. \\
\hline & & Beginning: December 1992.End: December 1996. \\
\hline & & Beginning: July 2001. End: January 2003. Significant \\
\hline \multirow[t]{7}{*}{ Paraguay } & KR & - \\
\hline & CK & 1995-1999 \\
\hline & & $2001-$ \\
\hline & LGS & Significant \\
\hline & FSI & Beginning: December 1982. End: November 1990. \\
\hline & & Beginning: January 1995. End: December 1998. \\
\hline & & Beginning: Febrero 2001. Peak: . End:. \\
\hline
\end{tabular}




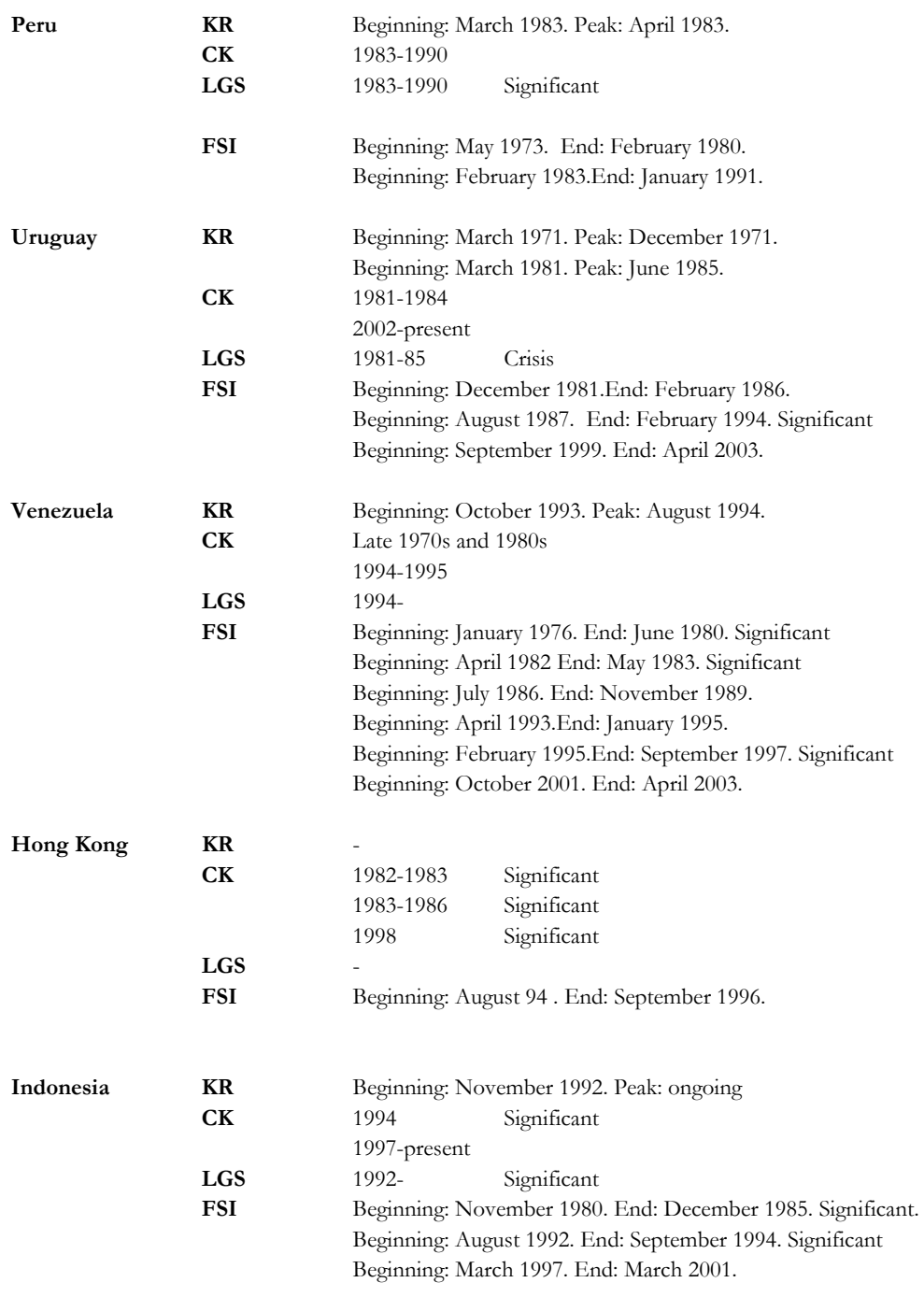




\begin{tabular}{|c|c|c|c|}
\hline \multirow[t]{4}{*}{ Korea } & KR & \multicolumn{2}{|l|}{-} \\
\hline & CK & \multicolumn{2}{|l|}{$1997-$} \\
\hline & LGS & Mid-1980s & Significant \\
\hline & FSI & \multicolumn{2}{|c|}{$\begin{array}{l}\text { Beginning: March 1972. End: December } 1976 . \\
\text { Beginning: May 1983. End: March 1989. Significant } \\
\text { Beginning: July 1997. End: March } 1999 .\end{array}$} \\
\hline \multirow[t]{4}{*}{ Malaysia } & KR & \multicolumn{2}{|c|}{$\begin{array}{l}\text { Beginning: July 1985. Peak: August } 1986 . \\
\text { Beginning: September 1992. Peak: .- }\end{array}$} \\
\hline & CK & \multicolumn{2}{|l|}{ 1985-1988 } \\
\hline & LGS & \multicolumn{2}{|l|}{ 1985-1988 } \\
\hline & FSI & \multicolumn{2}{|c|}{$\begin{array}{l}\text { Beginning: June } 1992 \text { End: March 1995. Significant } \\
\text { Beginning: June } 1996 . \text { End: August } 1998 .\end{array}$} \\
\hline \multirow[t]{7}{*}{ Philippines } & KR & \multicolumn{2}{|c|}{$\begin{array}{l}\text { Beginning: January 1981. Peak: June } 1985 . \\
\text { Beginning: July 1997. Peak: - }\end{array}$} \\
\hline & CK & \multicolumn{2}{|l|}{$1998-$} \\
\hline & LGS & \multicolumn{2}{|l|}{$1981-1987$} \\
\hline & FSI & \multicolumn{2}{|c|}{ Beginning: January 1972. End: January 1977.} \\
\hline & & \multicolumn{2}{|c|}{ Beginning: July 1983. End: September 1987.} \\
\hline & & \multicolumn{2}{|c|}{ Beginning: August 1990. End: September 1992. Significant } \\
\hline & & \multicolumn{2}{|c|}{ Beginning: February 1996. End: August 2002.} \\
\hline \multirow[t]{5}{*}{ Singapore } & KR & \multicolumn{2}{|l|}{-} \\
\hline & \multirow[t]{2}{*}{ CK } & 1982 & Significant \\
\hline & & 1982 & Minor problems \\
\hline & \multirow[t]{2}{*}{ FSI } & \multicolumn{2}{|c|}{ Beginning: October 1970. End: June 1974.} \\
\hline & & \multicolumn{2}{|c|}{ Beginning: June 1983. End: May 1990. Significant } \\
\hline \multirow[t]{5}{*}{ Japan } & KR & \multicolumn{2}{|l|}{-} \\
\hline & CK & \multicolumn{2}{|l|}{$1991-$} \\
\hline & LGS & \multicolumn{2}{|l|}{ 1992- } \\
\hline & & 1993 & Significant \\
\hline & FSI & \multicolumn{2}{|c|}{$\begin{array}{l}\text { Beginning: September 1973. End: November } 1978 . \\
\text { Beginning: April 1981. End: May } 1985 .\end{array}$} \\
\hline
\end{tabular}


Turkey

Israel

Denmark

Finland

Germany

Greece

KR

CK 1991-1995

LGS 1991-1995 Significant

FSI Beginning: August 1991. End: August 1994.

Iceland

KR -

Beginning: January 1991. Peak: March 1991.

1982-1985

$1994 \quad$ Significant

$2000-$

$1994 \quad$ Significant

Beginning: July 1972.End: June 1975 Significant.

Beginning: July 1977. End: May 1981

Beginning: December 1985. End: June 1989.

Beginning: June 1992. End: December 1994. Significant

Beginning: February 1997.End: November 2001

Beginning: October 1983. Peak: June 1984.

1977-1983

1983-1984 Significant

Beginning: January 1974. End: December 1975. Significant

Beginning: May 1977. End: August 1981.

Beginning: March 1987 . Peak: June 1990.

1987-1992 Significant

Beginning: September 1991. Peak: June 1992

1991-1994

1991-1994

Beginning: March 1973. End: March 1978

Beginning: July 1979. End: September 1981. Significant

Beginning: February 1986. End: March 1987. Significant

Beginning: February 1989. End: December 1993.

late $1970 \mathrm{~s} \quad$ Significant

1990-1993 Significant

Beginning: August 1975. End: March 1978. Significant

Beginning: February 1988. End: February 1992. Significant

CK 1985-1986 Significant

1993 Significant

$\begin{array}{ll}\text { LGS } & \text { 1985-1986 Significant } \\ \text { FSI } & \text { Beginning: April 1974. End: July } 1975 .\end{array}$

Beginning: July 1985. End: September 1986. Significant

Beginning: June 1992. End: November 1995.

Beginning: February 1997 End: November 02. 


\begin{tabular}{|c|c|c|c|}
\hline \multirow[t]{4}{*}{ Ireland } & KR & \multicolumn{2}{|l|}{-} \\
\hline & CK & \multicolumn{2}{|l|}{-} \\
\hline & LGS & 1985 & Significant \\
\hline & FSI & \multicolumn{2}{|c|}{$\begin{array}{l}\text { Beginning: February 1989. End: June 1990. Significant } \\
\text { Beginning: April 1992. End: March 1993. Significant }\end{array}$} \\
\hline \multirow[t]{4}{*}{ Italy } & KR & - & \\
\hline & CK & 1990-1995 & Significant \\
\hline & LGS & 1990-1995 & Significant \\
\hline & FSI & \multicolumn{2}{|c|}{$\begin{array}{l}\text { Beginning: August 1981.End: April 1986. Significant } \\
\text { Beginning: December 1989. End: June } 1995 .\end{array}$} \\
\hline \multirow[t]{6}{*}{ Norway } & KR & \multicolumn{2}{|c|}{ Beginning: November 1988. Peak: October 1991.} \\
\hline & CK & \multicolumn{2}{|l|}{$1987-1993$} \\
\hline & LGS & \multicolumn{2}{|l|}{$1987-1993$} \\
\hline & FSI & \multicolumn{2}{|c|}{ Beginning: July 1981.End: April 1983. Significant } \\
\hline & & \multicolumn{2}{|c|}{ Beginning: October 1985.End: November 1992.} \\
\hline & & \multicolumn{2}{|c|}{ Beginning: January 1998. End: August 2001. Significant } \\
\hline \multirow[t]{5}{*}{ Portugal } & KR & \multicolumn{2}{|l|}{ - } \\
\hline & CK & \multicolumn{2}{|l|}{ - } \\
\hline & LGS & \multicolumn{2}{|l|}{-} \\
\hline & FSI & \multirow{2}{*}{\multicolumn{2}{|c|}{$\begin{array}{l}\text { Beginning: October 1991. End: January 1993. Significant } \\
\text { Beginning: February 1993.End: December } 1995 .\end{array}$}} \\
\hline & & & \\
\hline \multirow[t]{6}{*}{ Spain } & KR & \multicolumn{2}{|c|}{ Beginning: November 1978. Peak: January 1983.} \\
\hline & CK & \multicolumn{2}{|c|}{$1977-1985$} \\
\hline & LGS & \multicolumn{2}{|l|}{$1977-1985$} \\
\hline & FSI & \multicolumn{2}{|c|}{ Beginning: January 1976. End: August 1979. Significant } \\
\hline & & \multicolumn{2}{|c|}{ Beginning: September 1979.End: April 1986.} \\
\hline & & \multicolumn{2}{|c|}{ Beginning: June 1992. End: January 1996.} \\
\hline \multirow[t]{6}{*}{ Sweden } & KR & \multicolumn{2}{|c|}{ Beginning: November 1991. Peak: September 1992.} \\
\hline & CK & \multicolumn{2}{|l|}{1991} \\
\hline & LGS & \multicolumn{2}{|l|}{$1990-1993$} \\
\hline & FSI & Beginning: & rember 1973. End: July 1975. Significant \\
\hline & & Beginning: & ember 1984. End: December 1985. Significant \\
\hline & & Beginning: & ust 1991.End: August 1993. \\
\hline United Kingdom & KR & - & \\
\hline & CK & 1974-1976 & Significant \\
\hline & & 1980 s and 1 & Significant \\
\hline & LGS & - & Minor problems \\
\hline & FSI & Beginning: & 1992. End: June 1996. \\
\hline
\end{tabular}




\begin{tabular}{|c|c|c|c|}
\hline \multirow{7}{*}{ Cameroon } & KR & \multicolumn{2}{|l|}{ - } \\
\hline & CK & \multicolumn{2}{|l|}{ 1987-1993 } \\
\hline & & \multicolumn{2}{|l|}{ 1995-1998 } \\
\hline & LGS & \multicolumn{2}{|l|}{ 1989-1993 } \\
\hline & & \multicolumn{2}{|l|}{$1995-$} \\
\hline & FSI & \multirow{2}{*}{\multicolumn{2}{|c|}{$\begin{array}{l}\text { Beginning: August 1977.End: June 1984. Significant } \\
\text { Beginning: July 1986. End: November } 1991 .\end{array}$}} \\
\hline & & & \\
\hline \multirow[t]{8}{*}{ Ghana } & KR & \multicolumn{2}{|l|}{ - } \\
\hline & CK & \multicolumn{2}{|l|}{ 1982-1989 } \\
\hline & LGS & \multicolumn{2}{|l|}{ 1989-1993 } \\
\hline & & \multicolumn{2}{|l|}{ 1995- } \\
\hline & FSI & \multicolumn{2}{|c|}{ Beginning: August 1981. End: May 1984. Significant } \\
\hline & & \multicolumn{2}{|c|}{ Beginning: March 1987. End: July 1990.} \\
\hline & & \multicolumn{2}{|c|}{ Beginning: August 1993. End: September 1996.} \\
\hline & & \multicolumn{2}{|c|}{ Beginning: October 1998. End: ?. } \\
\hline \multirow[t]{6}{*}{ Kenya } & KR & \multicolumn{2}{|l|}{-} \\
\hline & CK & \multicolumn{2}{|l|}{ 1985-1989 } \\
\hline & & \multicolumn{2}{|l|}{1992} \\
\hline & & \multicolumn{2}{|l|}{ 1993-1995 } \\
\hline & & 1996- & Significant \\
\hline & LGS & 1993 & Significant \\
\hline \multirow[t]{8}{*}{ Nigeria } & KR & \multicolumn{2}{|l|}{ - } \\
\hline & CK & \multicolumn{2}{|l|}{$1990 \mathrm{~s}$} \\
\hline & & 1997 & Significant \\
\hline & LGS & 1991-1995 & Significant \\
\hline & FSI & \multicolumn{2}{|c|}{ Beginning: January 1972. End: December 1977.} \\
\hline & & \multicolumn{2}{|c|}{ Beginning: January 1987.End: April 1989. Significant } \\
\hline & & \multicolumn{2}{|c|}{ Beginning: November 1990. End: August 1997.} \\
\hline & & Beginning: & ember 1998. End: November 2000. \\
\hline Senegal & KR & - & \\
\hline & CK & 1988-1991 & \\
\hline & LGS & 1983-1988 & \\
\hline & FSI & Beginning: & 1978. End: January 1984. Significant \\
\hline & & Beginning: & ust 1987.End: August 1993. \\
\hline & & Beginning: & 1997. End: April 2000. \\
\hline South Africa & KR & - & \\
\hline & CK & 1977 & Significant \\
\hline & & 1989-? & Significant \\
\hline & LGS & 1985 & \\
\hline & FSI & Beginning: & ober 1974. End: February 1981. Significant \\
\hline & & Beginning: & il 1985.End: June 1991. Significant \\
\hline
\end{tabular}


The following list intends to complement the survey of banking problems presented in this annex. It presents short comments regarding the classifications provided by CK, LGS, KR and this work.

\section{Argentina}

General comment: There exists a relatively high agreement among authors with respect to crisis dates. For the periods under consideration, there are no episodes of significant problems or borderline crisis.

Disagreements: The most significant discrepancy is given by KR, whom set the beginning of the second period of crises in 1985, a date that lies almost four years ahead from the other dates.

Potential problems: According to LGS, during the first year of 1980-1982, nonperforming loans (NPLs) were around 9\%. During the second crises period, 1989-1990, NPLs reached $27 \%$. But, even though NPLs reached 30\% in 1985, according to both CK and LGS, this year is not even a year of significant problems or borderline crises.

Comments on the new dates: The resulting chronology resembles the generally accepted dates.

\section{Bolivia}

General comment: Two periods of crisis or significant problems: 1986-1998 and 1994-present. Disagreements: The most significant discrepancy is given by KR, whom set the beginning of the second period of crises in 1985, a date that lies almost four years ahead from the other dates.

Potential problems: According to LGS, during the first year of 1980-1982, nonperforming loans (NPLs) were around 9\%. During the second crises period, 1989-1990, NPLs reached $27 \%$. But, even though NPLs reached 30\% in 1985, according to both CK and LGS, this year is not even a year of significant problems or borderline crises.

Comments on the new dates: The stress periods signaled by other works are also found with the present methodology, but with the last stage divided in two. The most notable difference is the inclusion of two periods to the chronology (1972-1974 and 1982-1986).

\section{Brazil}

General comment: The level of agreement is relatively low. LGS consider that Brazil confronted no financial crisis. KR date a first crisis in 1985 and then a second one in 19941996. Finally, CK also signal two episodes: the first in 1990 and the second in 1994-1999.

Disagreements: The crisis acknowledged by KR in 1985 -the same year for which the signal a crisis in Argentina- is not identified neither by LGS nor CK. KR and LGS do not date the 1990 's crisis signaled by CK. And in 1994, both KR and CK point the beginning of a financial crisis but LGS consider that is case of significant problems.

Potential problems: -

Comments on the new dates: Three episodes of high financial stress and one case of second order are signaled (this last is the only that does not overlap with any date from the works of KR, LGS or CK).

\section{Chile}

General comment: There exists a wide consensus on the 1980s' crisis.

Disagreements: CK point a systemic failure in 1976 that is not acknowledged by KR (the period is not covered by LGS).

Potential problems: -

Comments on the new dates: The present methodology identifies episodes cited in other works. Dates attached to 1980s' crisis are in line with the consensus. It also signals the 1976 crisis, but it is considered a more extended episode. Additionally, it is acknowledged the presence 
of secondary -no crisis- problems in 1997 (Chile has significant trade relationships with Asia).

\section{Colombia}

General comment: The agreement locates troubled years around 1982-1987

Disagreements: According to LGS, Colombia did not experienced financial crisis over the period. Besides, they consider the $1986-1987$ period as a tranquil one.

Potential problems: -

Comments on the new dates: The episode around the mid 1980s is identified, even though with a pause of 19 months. Additionally, a stage of mild turbulence is identified between the second half of 2001 and the first of 2002.

\section{Costa Rica}

General comment: Is not covered by KR's sample. CK point the presence of crises in "several instances" but without specifying dates. Both CK and LGS signal 1994 as the starting year of significant problems (or borderline crisis).

Disagreements: LGS do not acknowledged the presence of crisis or significant problems before 1994, as CK do.

Potential problems: CK do not clearly state their procedure to point the presence of crises in "several instances".

Comments on the new dates: Three crises are identified prior to 1994: 1970-1971, 1974-1975 and 1980-81. 1994 is also called as the beginning year of secondary problems ending in 1998.

\section{Ecuador}

General comment: Not covered by KR's sample. CK identify 3 periods of crisis: "early 1980s", 1996-1997 and 1998-present. LGS signal problems starting at 1995.

Disagreements: According to LGS there are no episodes of crisis, only significant problems since 1995.

Potential problems: -

Comments on the new dates: The crisis of the early 1980s is identified, as also is the crisis started in 1994. Additionally, a period of secondary problems is signaled between 1976 and 1979.

\section{Mexico}

General comment: There is agreement on the beginning dates of two episodes: in the early 1980s and the first half of the 1990s.

Disagreements: There exists a significant discrepancy over the 1980s' crisis. While for CK the crisis begin in 1981 and end in 1991, for CK only 1982 is a crisis year (over the rest of the 1980s they do not even point significant problems).

Potential problems: -

Comments on the new dates: Both periods of crises are identified. Additionally, a stage of secondary stress is identified between mid 2001 and 2003.

\section{Paraguay}

General comment: Not covered by KR's sample. There is agreement on the presence of financial problems on the second half of the 1990s.

Disagreements: For the second half of the 1990s CK evaluate the episode as a crisis, whilst LGS considerer them only as significant problems.

Potential problems: - 
Comments on the new dates: The episodes of the second half of the 1990s and early 2000s are identified. Additionally a stage of financial distress is called between 1983 and 1990.

\section{Peru}

General comment: All three works agree to date the beginning of problems in 1983. CK and LGS agree on the episode's extension.

Disagreements: CK consider the 1980s as crisis years, whilst LGS consider them as displaying significant problems.

Potential problems: Even in spite of the nationalization of the banking system, LGS consider that there was no crisis.

Comments on the new dates: Dates attached to 1980s' crisis are in line with those of LGS and CK. One additional period of crisis is identified between 1973 and 1980.

\section{Uruguay}

General comment: There is agreement on the presence of problems in the first half of the 1980s.

Disagreements: -

Potential problems: -

Comments on the new dates: Crises of the early 1980s and 2000s are identified. Additionally, the years between 1987 and 1993 are classified as of secondary problems.

\section{Venezuela}

General comment: There is agreement on the presence of a financial crisis during the mid 1990s.

Disagreements: CK identify episodes of borderline and smaller banking crisis through late 1970s and 1980s, that are not identified by LGS.

Potential problems: -

Comments on the new dates: The 1994-1995 crisis is identified. Also, two additionally episodes of crises are signaled, 1986-1989 and 2001-2003 and three periods of secondary problems in 1976-1980, 1982-1983 and 1995-1997.

\section{Hong Kong}

General commen: Relatively low agreement on the presence of financial problems.

Disagreements: CK consider that Hong Kong faced secondary problems between 1982 and 1986 and again in 1998. In the view of LGS, Hong Kong confronted neither crises nor significant problems.

Potential problems: -

Comments on the new dates: The case of Hong Kong is covered since 1994. Problems are identified in 1995 but not in 1998.

\section{Indonesia}

General comment: Relatively low agreement on dates and duration.

Disagreements: CK deem Indonesia entered in a period of crisis in 1997, but according to KR the crisis started in 1992. 1992-1996 is signaled by LGS as a stage of significant problems, while CK consider that only during 1994 Indonesia faced a borderline crisis.

Potential problems:-

Comments on the new dates: The 1992-1994 period is considered of secondary problems. The 1997 crisis is identified. Additionally, another episode of secondary problems is signaled. 1981-1985.

\section{Israel}


General comment: There exists a significant disagreement on the scale and dates of financial problems.

Disagreements: CK date the onset of a crisis in 1977 lasting until 1983. According to KR and LGS there are no problems before 1983, being that the year where problems actually started (a crisis in KR's view but only significant problems according LGS).

Potential problems: -

Comments on the new dates: A period of crisis is identified over a period in line with CK. Also, a period of secondary problems is signaled (1974-1975).

\section{Korea}

General comment: No covered by KR's sample. There exists disagreement on the presence of secondary problems during mid-1980s.

Disagreements: LGS signal significant problems during mid-1980s but this period is deemed as tranquil by CK.

Potential problems: -

Comments on the new dates:The 1997 crisis and 1980s' secondary problems are identified. Additionally, another episode of crisis is pointed during in mid-1970s (1972-1976).

\section{Malaysia}

General comment: There exists an intermediate agreement on the presence of financial problems.

Disagreements: According to KR and LGS during the mid-1980s the country experienced a crisis, but this episode is deemed of secondary magnitude by CK. The late-1990s crisis started in 1992 in KR's view and five year later for CK.

Potential problems:-

Comments on the new dates: Years prior to 1991 are not covered. Secondary problems are identified since 1992, before the 1997 crisis.

\section{Philippines}

General comment: There exists agreement on the presence of problems during the early and mid-1980s and also towards the end of the 1990s.

Disagreements:-

Potential problems:-

Comments on the new dates: The 1980s and 1990s problems are identified. Also an additional period of significant problems is identified through 1972-1976 and one of secondary magnitude during 1991-1992

\section{Singapore}

General comment: There is agreement on the presence of secondary problems in 1982.

Disagreements: -

Potential problems:-

Comments on the new dates: Two periods of crisis are identified: 1970-1974 and 1983-1990

\section{Turkey}

General comment: There is an intermediate agreement on the presence of problems.

Disagreements: KR count no problems during 1980s. LGS identify a crisis in 1982. According to CK, the 1982 crisis extended until 1985. In 1991 both KR and LGS signal a crisis, which is not acknowledged by CK.

Potential problems: - 
Comments on the new dates: 1980s' problems are identified, but over different periods: 19771981 and 1985-1989. A third episode is dated between 1997 and 2001. Also, two additional episodes of secondary magnitude are found: 1973-1975 and 1992-1994.

\section{Finland}

General comment: There is agreement on the presence of problems during the early 1990 s.

Disagreements:-

Potential problems:

Comments on the new dates: Early 1990s problems are identified. Also, the 1973-1978 period is classified as having similar problems and secondary problems are signaled over 1979-1981 and 1986-1987.

\section{Germany}

General comment: CK identify problems at the end of the 1970s, while LGS signal problems during the early 1990s.

Disagreements: CK do not acknowledge problems in the early 1990 s.

Potential problems:

Comments on the new dates: Late 1970s and early 1990s (beginning during the late 1980s) problems are identified.

\section{Greece}

General comment: Not covered in KR's sample. There is agreement on the presence of secondary problems between 1991 and 1995.

Disagreements:-

Potential problems: -

Comments on the new dates: Early 1990s problems are identified.

\section{Iceland}

General comment: Not covered by KR's sample. LGS and CK agree to signal secondary problems over two periods: 1985-1986 and 1993.

Disagreements: -

Potential problems: -

Comments on the new dates: Two episodes of high stress are identified. The first ranges from 1973 until 1978 and the second from 1981 to 1985.

\section{Ireland}

General comment: Not covered by KR's sample.

Disagreements: LGS identify significant problems during 1985. CK consider Ireland as a case with no financial problems.

Potential problems: -

Comments on the new dates: Two periods of secondary problems are identified: 1989-1990 and 1992-1993.

Italy

General comment: Not covered by KR's sample. There is agreement on the presence of problems during the first half of the 1990s.

Disagreements:-

Potential problems: -

Comments on the new dates: 1990s' problems are identified. Also, a period of secondary pressure is signaled between 1981 and 1986.

\section{Norway}


General comment: There exists a relatively high level of agreement on the presence of problems between the late 1980s and the early 1990s.

Disagreements:-

Potential problems: -

Comments on the new dates: Problems between mid 1980s and early 1990s are identified. Also, two periods of intermediate stress are signaled: 1981-1983 and 1998-2001.

\section{Portugal}

General comment: LGS, CK and KR find no problems.

Disagreements: -

Potential problems: -

Comments on the new dates: A period of low stress is identified in 1991-1992, followed by a stance of intermediate pressure in 1993-1995.

\section{Spain}

General comment: There is agreement on the presence of problems from late 1970s until mid 1980s.

Disagreements: -

Potential problems: -

Comments on the new dates: The problems covering the period late-1970s until mid-1980s is identified. Also, another stance of relatively high stress is signaled between 1992 and 1995.

\section{Sweden}

General comment: There is agreement on the presence of problems during the early 1990s, but consensus vanishes with respect its duration.

Disagreements: In LGS's view the crisis erupted in 1990, whilst for KR and CK the year is 1991. And according to CK 1992 is no longer a crisis year, but for LGS up to 1993 the crisis was still ongoing.

Potential problems: -

Comments on the new dates: The early 1990s' crisis is identified. Also, two period are highlighted as of intermediate stress: 1973-1975 and 1985.

\section{United Kingdom}

General comment: Not covered by KR's sample. There is an intermediate level of agreement. Disagreements: CK point the presence of secondary problems during the mid 1970s and at several points during the 1980s and 1990s. According to LGS's view these problems do not qualify as secondary problems.

Potential problems: -

Comments on the new dates: The covered period start in 1987. Early 1990s' problems are identified.

\section{Cameroon}

General comment: Not covered by KR. There is agreement on the presence of problems between late 1980s and early 1990s, and also in the mid 1990s.

Disagreements: According to LGS, problems started in 1989, but for CK they began as early as 1987.

Potential problems: -

Comments on the new dates: The mid 1990s' problems are not identified, but the late 1980s and early 1990s are. The period 1997-1984 is signaled as a stance of intermediate stress.

\section{Ghana}


General comment: Not covered by KR. There is high disagreement on the presence of financial problems.

Disagreements: CK identify a crisis between 1982 and 1989. According to LGS, the crisis didn't erupted until 1989 and ended in 1993. Then, LGS identify another episode starting 1995 which is not acknowledged by CK.

Potential problems: -

Comments on the new dates: The early 1980s are identified as a period of intermediate stress. Then, three periods of high stress are identified: 1988-1990, 1993-1996 and 1998-x.

\section{Kenya}

General comment: Not covered by KR. There is high disagreement on the presence of financial problems.

Disagreements: CK identify crisis in 1985-1989, 1992 and 1993-1995, and a borderline crisis since 1996. In LGS's view, only 1993 is a year of secondary problems.

Potential problems: -

Comments on the new dates: High levels of financial stress are identified in 1974-1975, 19921995 and 1997-2002 and intermediate levels in 1985-1986.

\section{Nigeria}

General comment: Not covered by KR. There is agreement on the presence of financial problems during the 1990 s.

Disagreements: -

Potential problems: -

Comments on the new dates: High levels of financial stress are identified in 1972-1977, 19901997 and 1998-2000 and intermediate levels in 1987-1989.

\section{Senegal}

General comment: Not covered by KR. Relatively high disagreement on the presence of problems.

Disagreements: LGS identify an episode of crisis in 1983-1988. This period is not acknowledged by CK, whom identify a crisis episode in 1988-1991 -which in turn is not acknowledged by LGS

Potential problems:-

Comments on the new dates: Two periods of high stress are identified, 1987-1993 and 19972000, and an additional one of intermediate pressure: 1978-1984.

\section{South Africa}

General comment: Not covered by KR. Relatively high disagreement on the presence of problems.

Disagreements: CK signal borderline problems in 1977 and 1989-?. LGS identify a crisis in 1985.

Potential problems: -

Comments on the new date

Two periods of intermediate stress are identified, 1974-1981 and 1985-1991. 


\section{Bibliography}

Berg, Andrew and Catherine Pattillo, 1999, "Predicting Currency Crises: The Indicators Approach and an Alternative.", Journal of International Money and Finance, 18 (1999) 561-586.

Bordo, M and Anna Schwartz, 2000, "Measuring Real Economic Effects of Bailouts: Historical Perspectives on How Countries in Financial Distress Have Fared With and Without Bailouts", NBER Working Paper \# 7701

Bordo, M., M.J. Dueker, and D.C. Wheelock, 2000, “Aggregate Price Shocks and Financial Insta-bility: An Historical Analysis", NBER Working Paper \#. 7652.

Bordo, M., M.J. Dueker, and D.C. Wheelock, 2000, "Aggregate Price Shocks and Financial Insta-bility: An Historical Analysis.” NBER Working Paper No. 7652.

Caprio, Gerard and Daniela Klingebiel, 2003, "Episodes of Systemic and Borderline Financial Crises". World Bank.

Chant, John, 2003, "Financial Stability As a Policy Goal," in Essays on Financial Stability, by John Chant, Alexandra Lai, Mark Illing, and Fred Daniel, Bank of Canada Technical Report No. 95

Crockett, Andrew, 1997, "The Theory and Practice of Financial Stability," GEI Newsletter Issue No. 6

Demirgüç-Kunt, A. and E. Detragiache, 1998, "The Determinants of Banking Crises in Developing and Developed Countries”, IMF Staff Papers 45(1): 81-109.

Diamond, Douglas W., and Philip H. Dybvig. 1983. "Bank Runs, Deposit Insurance, and Liquidity.” Journal of Political Economy 91 (3) :401--19.

Eichengreen, Barry and Carlos Arteta, 2000, "Banking Crises in Emerging Markets: Presumptions and Evidence", Center for International Development Economics Research Working paper 115, Haas School of Business, University of California Berkeley.

Eichengreen, Barry and Michael Bordo, Crises Now and Then: Lessons From the Last Era of Financial Globalization”, NBER Working Paper \# 8716

Ferguson, Roger, 2002, "Should Financial Stability Be An Explicit Central Bank Objective?”, Federal Reserve Board.

Freixas, Xavier and Jean-Charles Rochet, 1999, "Microeconomics of Banking", Massachusetts Institute of Technology.

Frydl, Edward J., 1999, “The Length and Cost of Banking Crises”, International Monetary Fund, Working Paper 99/30.

Illing, Mark and Ying Liu, 2003, "An Index of Financial Stress for Canada" Bank of Canada Working Paper No. 2013-14.

Kaminsky, Graciela L, 2003, "Varieties of Currency Crises”, NBER Working Papers 10193.

Kaminsky, Graciela L., and Carmen M. Reinhart, 1999, "The Twin Crises: The Causes of Banking and Balance-of-Payments Problems", American Economic Review (March)

Krugman, Paul, 1979, “A Model of Balance-of-Pay-ments Crises", Journal of Money, Credit, and Banking, August 1979, 11 (3), pp. 311-25. 
Lindgren, Carl-Johan, Gillian García and Matthew I. Saal, 1996, "Bank Soundness and Macroeconomic Policy", Washington, International Monetary Fund.

Mishkin, Frederic S., 2000, "Financial Policies and the Prevention of Financial Crises in Emerging Market Economies”, NBER Working Paper.

Schinasi, Garry J., 2004, "Defining Financial Stability", International Monetary Fund, Working Paper 04/187

Stiglitz, J. and A. Weiss, 1981, "Credit Rationing in Markets with Imperfect Information", American Economic Review, 62: 66-76

Stiglitz, J. and A. Weiss, 1983, "Incentive Effects of Terminations: Applications to the Credit and Labor Markets”, American Economic Review, 73(5): 393-410. 